University of Nebraska - Lincoln

DigitalCommons@University of Nebraska - Lincoln

Papers in the Earth and Atmospheric Sciences

Earth and Atmospheric Sciences, Department

2020

\title{
MOD\$AT: A hydro-economic modeling framework for aquifer management in irrigated agricultural regions
}

Mani Rouhi Rad

Erin M.K. Haacker

Vaishali Sharda

Soheil Nozari

Zaichen Xiang

See next page for additional authors

Follow this and additional works at: https://digitalcommons.unl.edu/geosciencefacpub

Part of the Earth Sciences Commons

This Article is brought to you for free and open access by the Earth and Atmospheric Sciences, Department of at DigitalCommons@University of Nebraska - Lincoln. It has been accepted for inclusion in Papers in the Earth and Atmospheric Sciences by an authorized administrator of DigitalCommons@University of Nebraska - Lincoln. 
Authors

Mani Rouhi Rad, Erin M.K. Haacker, Vaishali Sharda, Soheil Nozari, Zaichen Xiang, A. Araya, Venkatesh Uddameri, Jordan Suter, and Prasanna Gowda 


\title{
MOD\$\$A: A hydro-economic modeling framework for aquifer management in irrigated agricultural regions ${ }^{\text {th }}$
}

\author{
Mani Rouhi Rad ${ }^{\mathrm{a}, *}$, Erin M.K. Haacker ${ }^{\mathrm{b}}$, Vaishali Sharda ${ }^{\mathrm{c}}$, Soheil Nozari ${ }^{\mathrm{d}}$, Zaichen Xiang ${ }^{\mathrm{e}}$, \\ A. Araya ${ }^{\mathrm{f}}$, Venkatesh Uddameri ${ }^{\mathrm{g}}$, Jordan F. Suter ${ }^{\mathrm{h}}$, Prasanna Gowda ${ }^{\mathrm{i}}$

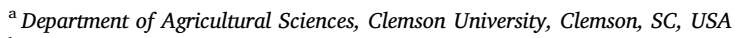 \\ ${ }^{\mathrm{b}}$ Department of Earth and Atmospheric Sciences, University of Nebraska Lincoln, Lincoln, NE, USA \\ ${ }^{\mathrm{c}}$ Department of Biological and Agricultural Engineering, Kansas State University, Manhattan, KS, USA \\ ${ }^{\mathrm{d}}$ Department of Civil and Environmental Engineering, Colorado State University, Fort Collins, CO, USA \\ ${ }^{\mathrm{e}}$ Department of Civil and Environmental Engineering, Colorado State University, Fort Collins, CO, USA \\ ${ }^{\mathrm{f}}$ Department of Agronomy, Kansas State University, Manhattan, KS, USA \\ ${ }^{\mathrm{g}}$ Department of Civil, Environmental and Construction Engineering, Texas Tech University, Lubbock, TX, USA \\ ${ }^{\mathrm{h}}$ Department of Agricultural and Resource Economics, Colorado State University, Fort Collins, CO, USA \\ ${ }^{\mathrm{i}}$ USDA-ARS Southeast Area, Stoneville, MS, USA
}

\section{A R T I C L E I N F O}

\section{Keywords:}

Hydro-economic modeling

Ogallala

High plains aquifer

Groundwater management

Policy analysis

Irrigation

\begin{abstract}
A B S T R A C T
In this paper, we introduce a hydro-economic modeling framework for the management of groundwater resources that are used for irrigated agricultural production. The model, MOD\$\$AT, can be used to study the costs of aquifer depletion and the net benefits of specific aquifer management policies. MOD\$\$AT is composed of three components, namely, an economic component, a hydrologic component and an agronomic component. A main goal of this paper is to introduce the hydro-economic model and describe how it can be transferable to different contexts. With this objective in mind, we describe model components step-by-step so that the process of integration can be replicated easily. We then apply the model to study the efficacy of a pumping tax in Finney County, Kansas, USA, which overlies the High Plains Aquifer. The results show that a pumping tax results in an increase in average well capacities in the county over time relative to the status quo, which increases the average profitability of agricultural production. However, the increase in profitability is not uniform across producers and some producers gain more than others under the tax.
\end{abstract}

\section{Introduction}

Since the advent of pumping technology, groundwater has supported agricultural production across the world in areas with and without significant surface water flows (Rodell et al., 2018). The decline of aquifers, along with changing climatic conditions, has led to concerns about the sustainability of current irrigation practices. Local communities that rely heavily on groundwater-fed agricultural production can be impacted by aquifer depletion (Almas et al., 2004). This is compounded by the fact that aquifers replenish slowly, if at all, which implies a low threshold for overuse. Furthermore, aquifers are common property resources that are shared among many producers that use groundwater for irrigation. Groundwater extraction by one user affects aquifer levels at neighboring wells, affecting the productivity and profitability of the neighboring wells.

Hydro-economic models are important tools for studying the effectiveness of water management policies (Brown et al., 2015; Harou et al., 2009). These integrated models (Haacker et al., 2019; Voinov and Shugart, 2013) attempt to leverage the strengths of both physical models and economic models to study the costs and benefits of different policies and associated changes in physical and climatic systems (Adamowicz et al., 2019). An ideal hydro-economic model for irrigation incorporates the water cycle, crop water use and growth, and the effect of incentives and externalities resulting from the interplay between the

\footnotetext{
4T "This article is based upon work that is supported by the National Institute of Food and Agriculture, U.S. Department of Agriculture, under award number 201668007-25066, "Sustaining agriculture through adaptive management to preserve the Ogallala aquifer under a changing climate."

* Corresponding author.

E-mail addresses: rrad@clemson.edu (M. Rouhi Rad), ehaacker2@unl.edu (E.M.K. Haacker), vsharda@ksu.edu (V. Sharda), soheil.nozari@colostate.edu (S. Nozari), Zaichen.Xiang@colostate.edu (Z.Xiang), aberhe@ksu.edu (A. Araya), venki.uddameri@ttu.edu (V. Uddameri), jordan.suter@colostate.edu (J.F. Suter), Prasanna.Gowda@usda.gov (P. Gowda).
} 
physical systems and producer irrigation decisions.

Traditionally, when addressing questions about the trends of aquifer depletion or the effectiveness of aquifer management policies, each of the disciplinary literatures in hydrology, agronomy, and economics have made simplifying assumptions about the elements and parameters of the other models (Harou et al., 2009). For example, hydrologic-based studies have attempted to calculate the remaining life of the aquifer based on historical patterns, without regard to changing incentives from increased extraction costs or decreased well capacities (Fenichel et al., 2016; Scanlon et al., 2012; Steward et al., 2013). These hydrologic models often assume that human impacts on fluxes are constant, minimal, or both. They may not respond realistically to variability, such as droughts, during which farmers often reduce their irrigated acreage in addition to watering more intensely in areas that remain irrigated (Deines et al., 2019). Furthermore, traditional hydrologic or hydroeconomic models do not operate at the producer-level and units of decision making are often aggregated (Mulligan et al., 2014).

This simplification of the behavioral assumptions can result in overestimating or under-estimating the rate of aquifer depletion. On the other hand, economic studies have focused on gains to management by simplifying the representation of hydrologic and agronomic systems in hydro-economic modeling endeavors (Gisser and Sánchez, 1980; Guilfoos et al., 2016). Simplifying assumptions on hydrological and agronomic processes can result in unrealistic estimates of crop water demand and yield response, and incorrect spatial distributions of benefits and costs to producers (Brozović et al., 2010; Koundouri, 2004).

In this paper, we introduce a hydro-economic framework for irrigation modeling that integrates hydrologic, agronomic, and economic models, named MOD\$\$AT. The model integrates three elements that are critical for studying irrigation-based agricultural systems: a hydrological model (MODFLOW), an agronomic model (Decision Support System for Agrotechnology Transfer, DSSAT), and a custom economic decision-making model.

The main utility of the MOD\$AT model is in how it can be used to empirically study how long-term aquifer depletion and different management policies across space and over time affect producers' profits. MOD\$AT makes this possible by modeling changes in aquifer levels and well capacities for all the wells across the aquifer and modeling the effect of changing well capacities on irrigated profits. This could allow one to observe declines in the predicted profitability of groundwater use over time as depletion reduces well capacities.

In addition to introducing the modeling framework, we provide some results from model runs with and without a tax on groundwater use. We also discuss the challenges that arise when developing such hydro-economic models, provide a discussion of the trade-offs in the form of judgment calls for addressing them and discuss directions for future research.

We demonstrate our model for a case-study of Finney County in the southwest of Kansas, USA, which overlies the High Plains Aquifer (HPA). However, the framework is easily applicable to different study areas. Given the importance of the HPA for agricultural production, in addition to our contributions to hydro-economic model development, the results from the illustrative case-study are also of direct benefit to a wide range of stakeholders in a critical agricultural region within the United States.

This paper contributes to the hydro-economic modeling literature (Haacker et al., 2019; Harou et al., 2009; George et al., 2011; Das et al., 2013; Medellín-Azuara et al., 2015), and more broadly to the integrated modeling literature, such as (Housh et al., 2015), by introducing a hydro-economic model of groundwater use in agricultural regions that integrates three critical elements that are necessary for modeling an agricultural system, namely, an economic model of producer decision making at the parcel-level, a crop simulation model, and a model of the physical groundwater system at a parcel-level. Our parcel-level production model, along with a spatially-explicit groundwater model, allows us to study the spatial distribution of costs and benefits across groundwater users. Similar studies, such as (Jaeger et al., 2017), have used parcel-level hydro-economic models but have simplified agricultural producers' irrigation decisions. MOD \$ \$AT includes a structural model of intra-seasonal irrigation decision making that utilizes simulated agronomic production relationships generated using DSSAT. As a result, we believe that MOD\$\$AT is more suitable than other studies for studying groundwater management in irrigated agricultural regions.

Furthermore, groundwater depletion has become a major issue across many aquifers. A major utility of hydro-economic models is to provide insight into development and analysis of existing and new policies for managing aquifers. However, an impediment for the adoption of integrated hydro-economic models has been the need for development of new software and programs (Bulatewicz et al., 2010). Moreover, many hydro-economic studies rely on very complex models that provide a "black-box feel"; they are difficult to fully understand and adapt to other use cases (Harou et al., 2009; Kahil et al., 2016; Voinov and Shugart, 2013). As a result, a model that can easily be used in other contexts could be very important. The model presented here uses three open source components, i.e., MODFLOW, DSSAT, and an economic model based on $\mathrm{R}$ language, that are freely available across the world and can easily be modified for different contexts. Specifically, MODFLOW and DSSAT have been used in many different contexts for hydrological and agricultural analysis and the custom R code and the Windows batch code is written by the authors and is publicly available on Github (https://github.com/manirouhirad/MODSSAT). The modular nature of MOD\$\$A also provides the advantage of a high degree of confidence in each model element as they are produced by academics in the respective disciplines (MacEwan et al., 2017). The open source nature of our model is similar to that of Dogan et al., 2018. While they focus on large-scale regional planning problems in California, our model focuses on groundwater management in agricultural regions with parcel-level decision-making units.

\section{Study area}

Finney County in the southwest of Kansas, USA, overlies the HPA (Fig. 1). HPA is the largest freshwater aquifer in the world and is the main source of water supply for irrigated agriculture in the county. Finney County is one of the most intensely irrigated areas overlying the HPA. Over $25 \%$ of the county's area has been dedicated to irrigated agriculture since the 1970's. The most dominant cultivated crops on the irrigated acreage in the county are corn, winter wheat, and sorghum. The HPA is the main source of water supply for irrigation. Some parcels along the Arkansas River historically were irrigated by diverting water from the Arkansas River (Fig. 1). However, due to lack of flow in the river, the amount of groundwater extracted from the HPA increased substantially during the 1970's (Whittemore, 2012). Subsequently, saturated thickness levels started declining across the county (Fig. 2).

There are seven major soil types in our study area that differ in terms of their productivity (Table 1 ). These soil types cover more than $90 \%$ of the agricultural acreage in Finney County. The average annual temperature over the past 30-year period in Finney County is $12.36 \mathrm{C}$ while the average 30-year temperature on the High Plains portion of Kansas overall is $12.33 \mathrm{C}$. Average precipitation in the same period over the irrigated portion of KS was $509 \mathrm{~mm}$, while 30-year precipitation over the High Plains portion of KS was $577 \mathrm{~mm}$. Average saturated thickness in Finney County between 1980 and 2017 was around $140 \mathrm{~m}$. Over the same period, average saturated thickness of the High Plains portion of Kansas was about $70 \mathrm{~m}$.

\section{MOD\$\$AT}

To provide insight into the effects of groundwater conservation policies on producers' profits in irrigated areas, a hydro-economic model for agricultural production is required. This model must consist of three main system components: a model of water balance and flux, a 


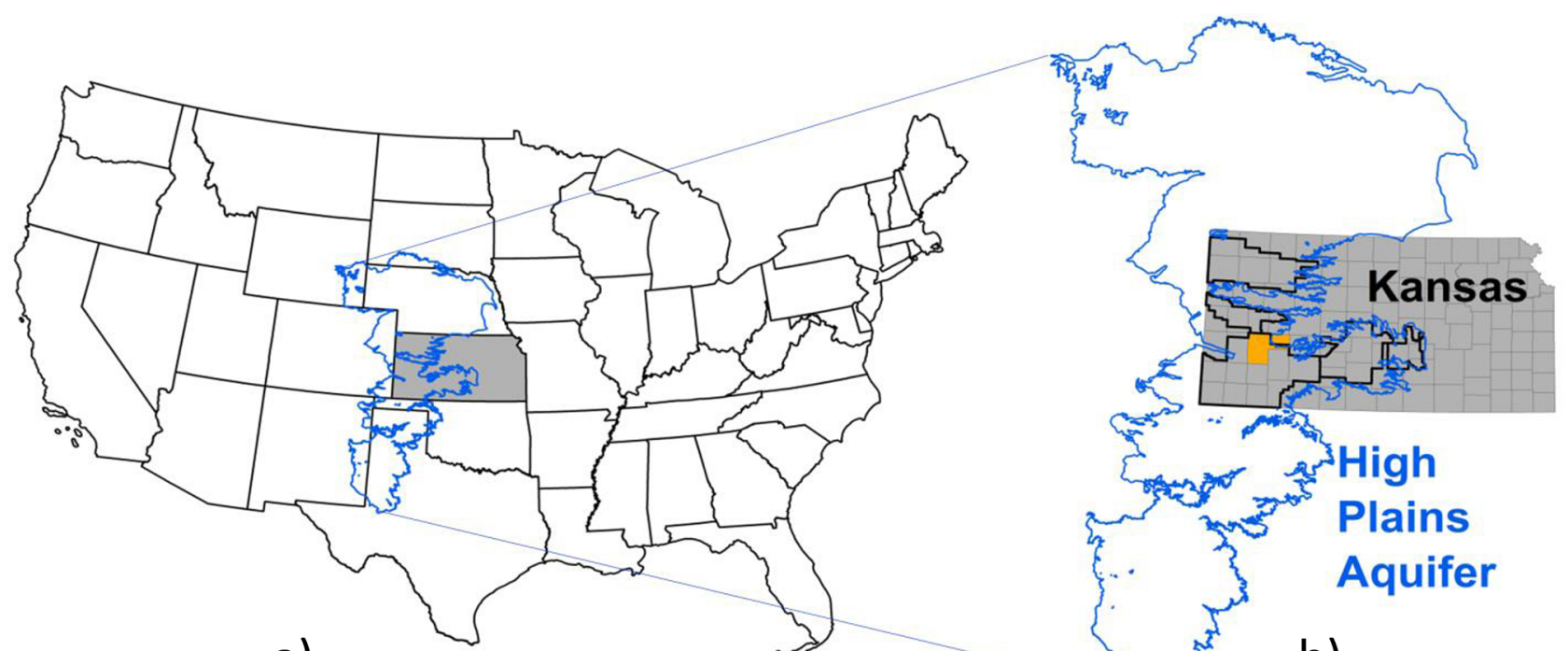

a)

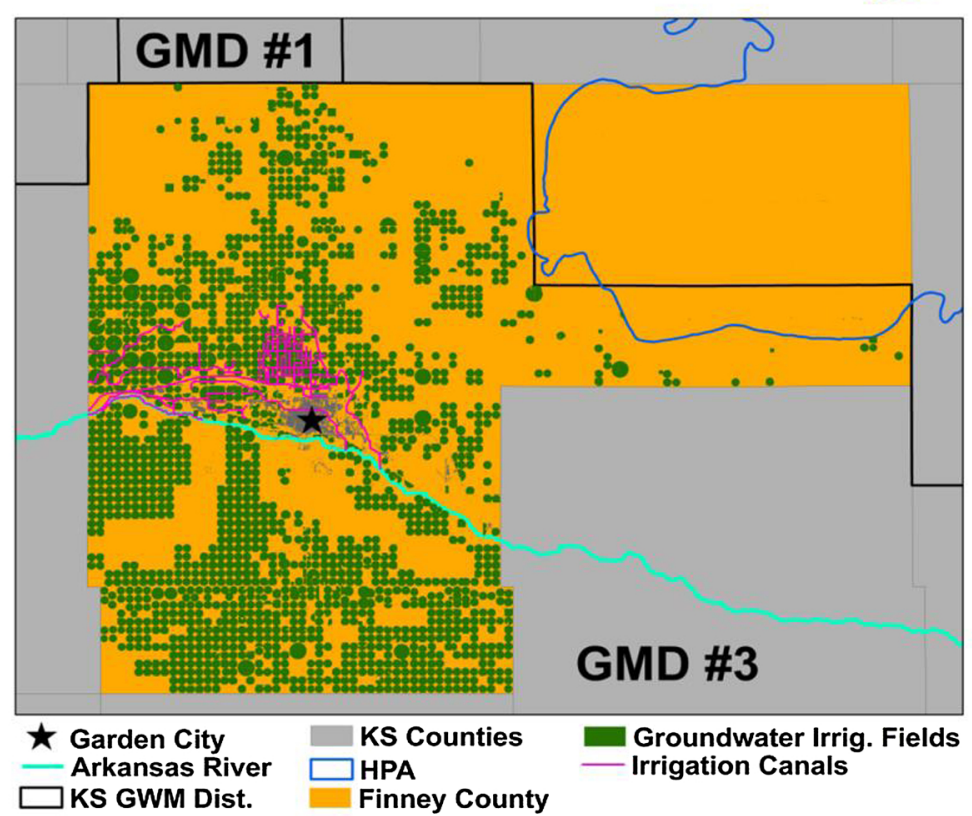

c)

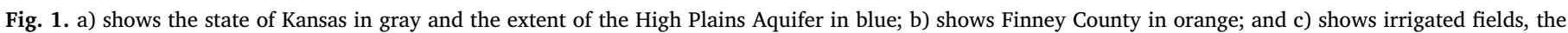
Arkansas River and the extent of groundwater management districts.

model of plant growth and yield, and a model of producer decision making. These components, i.e., hydrologic model, crop model, and economic model, are often simulated using independent, standalone models from different disciplines (Fig. 3a). The MOD\$\$AT model integrates these elements to create an interactive model of water flow, crop water use, and irrigation decision making that incorporates the feedbacks between these models (Fig. 3b). This explicit integration is the strength of a hydro-economic model, provided that the conceptual assumptions of each sub-model are compatible (Voinov and Shugart, 2013). For an integrated model to be effective, each element of the model should be considered a valid model within its respective discipline. However, as mentioned earlier, any single component is not enough for providing policy-relevant analysis and studying the effects of long-term changes such as climate change and aquifer depletion, because of the sensitivity to dynamic factors in other parts of the system. Removing any of the components without proper replacement can result in unrealistic physical or policy outcomes.

We start by explaining the generation of crop production functions for different crops and under different management strategies. We then describe the economic component of the model that includes producers' objective function and decision space. Finally, we discuss how these groundwater use decisions affect water levels across the aquifer by describing the hydrologic model.

\subsection{Crop production component}

Crop Simulation Models (CSM) can be used for research information synthesis, as tools for optimizing crop system management, and for policy analyses (Boote et al., 1996). These models are physically-based models that often involve collections of empirical relationships that are coupled with water and nutrient budgets and can simulate the growth, development, and yield of a crop (Monteith, 1996) along with the 


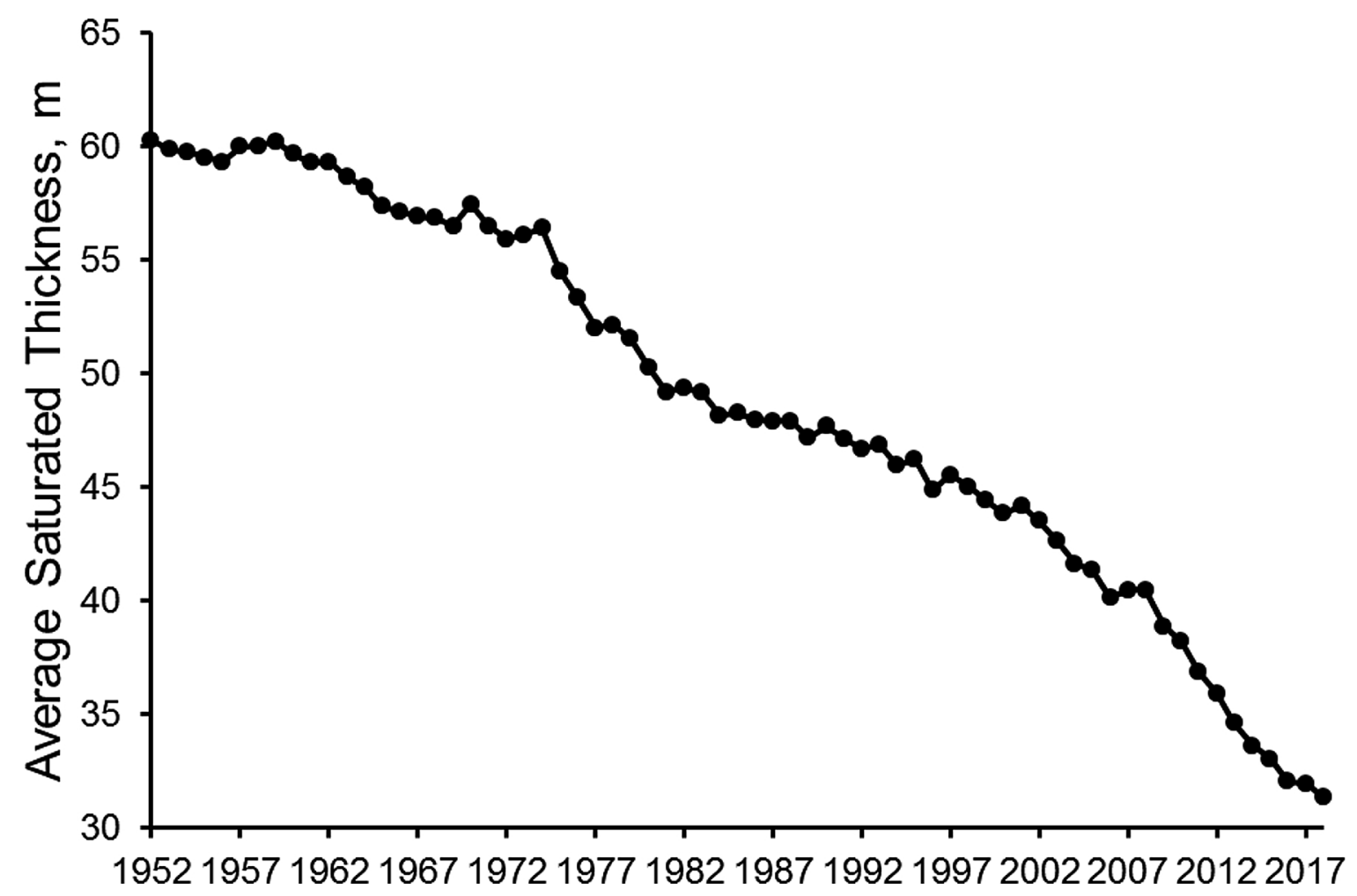

Fig. 2. Changes in saturated thickness in Finney County over time.

concomitant water cycle and nutrient dynamics. CSMs make it easier for users to select a combination of management practices based on the input data available, climatic and soil conditions, and conventional water management techniques.

In MOD\$\$AT, we use DSSAT (Hoogenboom et al., 2017; Jones et al., 2003), which is one of the most widely used CSMs for evaluating agricultural management options (Thorp et al., 2008) and for studying the impact of management strategies for different soil and climate conditions (McNider et al., 2015). The DSSAT version 4.7 comprises models for more than 42 crops that simulate crop growth, development, and yield along with management strategies that involve irrigation, fertilizer application, crop rotations, and others (Sharda et al., 2019). The model calculates crop growth and simulates water and nutrient balance at a daily time step by simulating processes of soil water, nutrient, and plant growth, along with developmental processes for the formation of final crop yield and yield components.

Though DSSAT has seen wide adoption as a standalone model to study the impact of environmental modifications on crop production

Table 1

Characteristics of the main soil types in Finney County, KS used in the MOD\$\$AT model.

\begin{tabular}{|c|c|c|c|c|c|c|c|c|c|}
\hline Soil type & Depth (cm) & $\mathrm{pH}$ & $\mathrm{CEC}(\mathrm{cmol} / \mathrm{kg})$ & TN\% & $\mathrm{LL}(\mathrm{mm} / \mathrm{mm})$ & DUL $(\mathrm{mm} / \mathrm{mm})$ & SWC (mm/mm) & $\mathrm{BD} \mathrm{g} / \mathrm{cm}^{3}$ & $\mathrm{SAT}(\mathrm{cm} / \mathrm{h})$ \\
\hline \multirow[t]{4}{*}{ Richfield silt loam } & 15 & 6.5 & 19 & 0.12 & 0.202 & 0.414 & 0.488 & 1.25 & 3.3 \\
\hline & 43 & 6.5 & 30 & 0.12 & 0.263 & 0.454 & 0.517 & 1.18 & 1.02 \\
\hline & 64 & 6.5 & 20 & 0.11 & 0.19 & 0.388 & 0.522 & 1.18 & 1.02 \\
\hline & 201 & 6.5 & 17 & 0.1 & 0.168 & 0.332 & 0.506 & 1.23 & 3.3 \\
\hline \multirow{4}{*}{$\begin{array}{l}\text { Ulysses } \\
\text { silt loam }\end{array}$} & 20 & 6.5 & 22 & 0.12 & 0.199 & 0.402 & 0.446 & 1.37 & 3.3 \\
\hline & 36 & 6.5 & 24 & 0.12 & 0.203 & 0.398 & 0.467 & 1.32 & 1.02 \\
\hline & 71 & 6.5 & 24 & 0.11 & 0.186 & 0.367 & 0.471 & 1.32 & 1.02 \\
\hline & 201 & 6.5 & 20 & 0.1 & 0.166 & 0.334 & 0.466 & 1.34 & 3.3 \\
\hline \multirow[t]{2}{*}{ Valent fine sand } & 43 & 6.5 & 9 & 0.12 & 0.121 & 0.228 & 0.442 & 1.4 & 10.16 \\
\hline & 152 & 6.5 & 7 & 0.12 & 0.106 & 0.206 & 0.427 & 1.45 & 10.6 \\
\hline \multirow[t]{4}{*}{ Satanta loam } & 25 & 6.5 & 15 & 0.12 & 0.172 & 0.342 & 0.451 & 1.34 & 3.3 \\
\hline & 61 & 6.5 & 20 & 0.12 & 0.176 & 0.312 & 0.442 & 1.4 & 1.02 \\
\hline & 122 & 6.5 & 11 & 0.11 & 0.126 & 0.252 & 0.442 & 1.4 & 1.02 \\
\hline & 201 & 6.5 & 13 & 0.1 & 0.135 & 0.272 & 0.426 & 1.45 & 3.3 \\
\hline \multirow[t]{4}{*}{ Beeler silt loam } & 20 & 6.5 & 17 & 0.12 & 0.2 & 0.405 & 0.459 & 1.33 & 2.8 \\
\hline & 61 & 6.5 & 16 & 0.12 & 0.203 & 0.388 & 0.467 & 1.33 & 2.65 \\
\hline & 142 & 6.5 & 16 & 0.11 & 0.182 & 0.351 & 0.469 & 1.33 & 2.8 \\
\hline & 210 & 6.5 & 17 & 0.1 & 0.186 & 0.339 & 0.498 & 1.25 & 2.62 \\
\hline \multirow[t]{3}{*}{ Las Clay loam } & 20 & 6.5 & 17 & 0.12 & 0.201 & 0.308 & 0.442 & 1.4 & 1.02 \\
\hline & 79 & 6.5 & 16 & 0.12 & 0.181 & 0.297 & 0.424 & 1.45 & 1.02 \\
\hline & 152 & 6.5 & 16 & 0.11 & 0.058 & 0.132 & 0.292 & 1.55 & 33.02 \\
\hline \multirow[t]{2}{*}{ Manter fine Sandy loam } & 43 & 6.5 & 9 & 0.12 & 0.121 & 0.228 & 0.442 & 1.4 & 10.16 \\
\hline & 152 & 6.5 & 7 & 0.12 & 0.106 & 0.206 & 0.427 & 1.45 & 10.6 \\
\hline
\end{tabular}

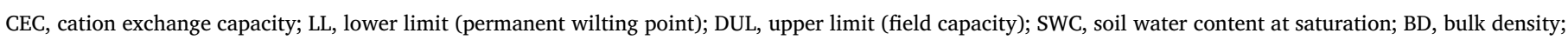
SAT, soil hydraulic conductivity. 


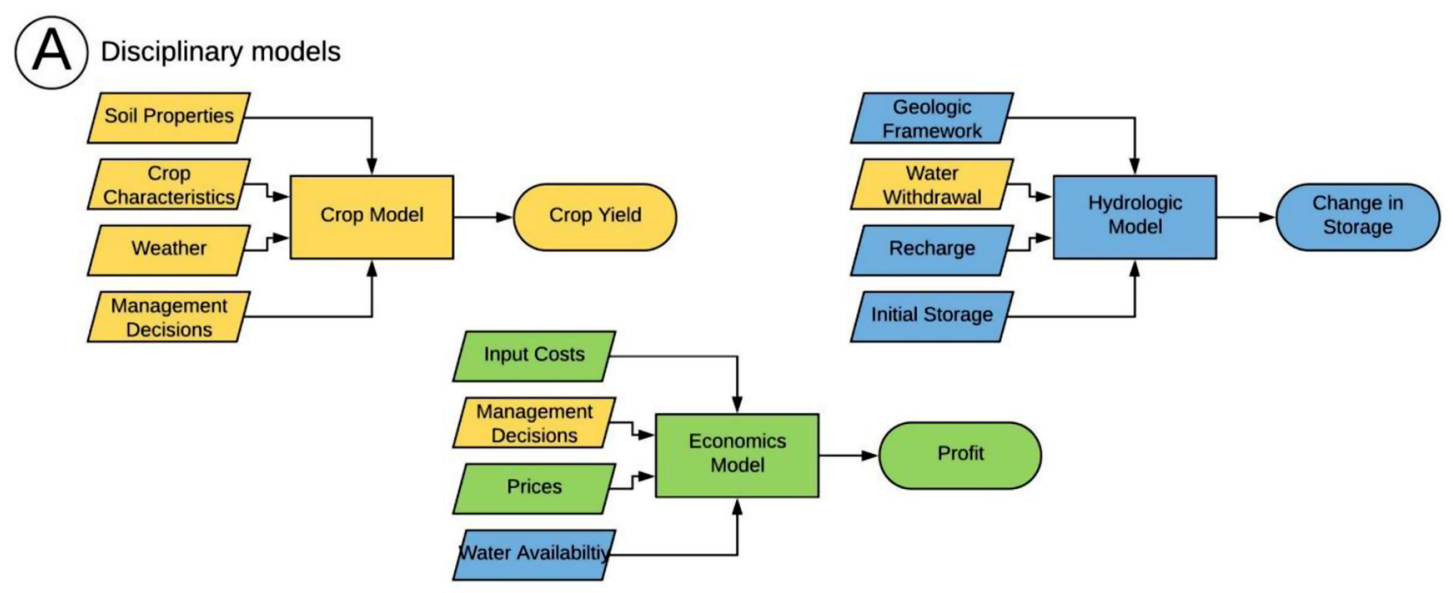

(B)

Hydroeconomics model

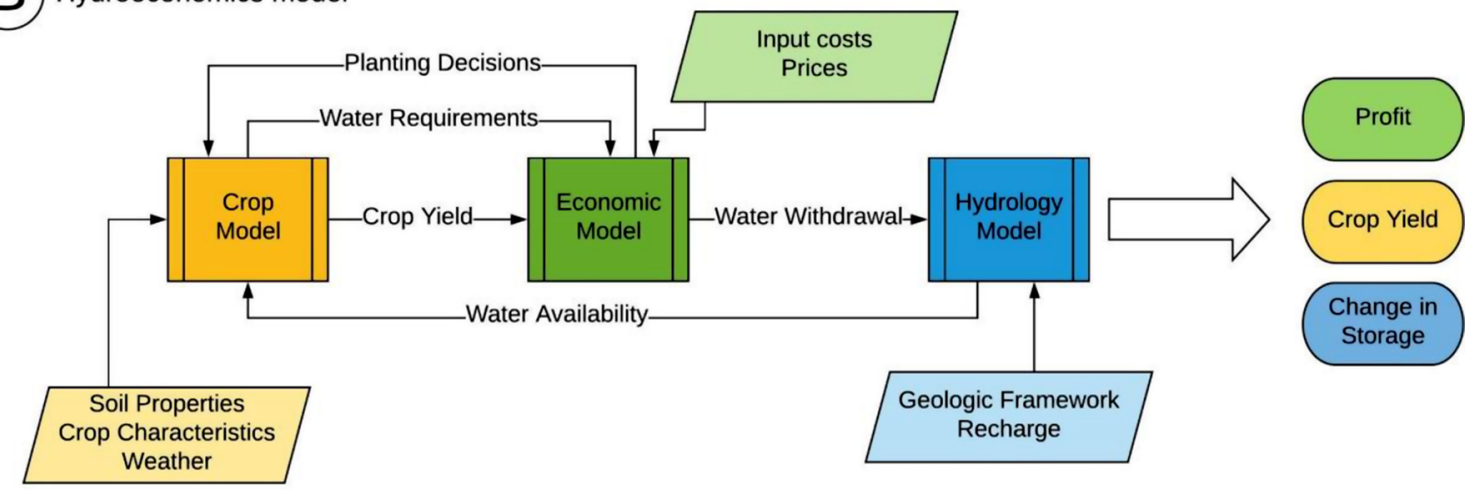

Fig. 3. Figure A shows the elements of each of the disciplinary models while Figure B shows the elements of the hydro-economic model.

systems, its application in conjunction with hydro-economic models has been limited (McNider et al., 2015). Several studies have developed water production functions under different irrigation management scenarios to study alternate irrigation strategies (Araya et al., 2018, 2019; Foster and Brozović, 2018; Mitchel et al., 2016) but these studies are limited in terms of their complexity in modeling hydro-economic dynamic systems.

Irrigation scenarios in DSSAT are developed for a unit area (a representative hectare), using a combination of the Critical Plant Available Water $\left(P A W_{c}\right)$ and Irrigation Frequency (IFREQ).

$P A W_{c}$ is the threshold where irrigation is triggered when plant available water in the soil root zone falls below this threshold (Kisekka et al., 2016). Each irrigation event can only start after the previous event has irrigated all irrigated acres and when there is enough well capacity. IFREQ is the minimum number of days between the start of two irrigation applications. Combinations of $P A W_{c}$ and IFREQ determine the timing and duration of irrigation applied. Triggering irrigation at higher $P A W_{c}$ for a shorter IFREQ can be beneficial during certain growth stages of a crop but might not be applicable during a different growth stage or for a different crop.

A declining well capacity affects IFREQ unless the number of irrigated acres is reduced. DSSAT produces water use and crop yield for a unit area (a hectare). As a result, we simulate various combinations of $P A W_{c}$ and IFREQ for three of the major crops in our study area, namely, corn, sorghum and wheat, to study the effect of changes in well capacity on irrigation and crop yield. In order to study the effects of aquifer depletion and declining well capacities on crop yield and profitability, in our crop simulations, we capture a range of well capacities and irrigated acres by simulating all crop yields and water uses for each crop using combinations of $P A W_{c} 25 \%$ (which means that irrigation is triggered when PAW falls below $25 \%$ ), $35 \%, 45 \%, 55 \%, 65 \%$, and 75
$\%$ and IFREQ of $2,4,6,8,10,12,14,16,18,20,22$ and 24 days. These combinations allow us to consider a range of groundwater availability and irrigation management that are consistent with groundwater availability and irrigation decisions in our study area. We also consider rainfed production for each crop which does not depend on aquifer levels.

All dryland simulations and irrigated simulations for the aforementioned combinations of IFREQ and $P A W_{c}$ are run for seven different soil types in our study area that are different in terms of their productivity (Table 1). Soil data for crop production models are obtained from the SSURGO database. The database includes specific details about soil characteristics, such as field capacity, wilting point and water content at saturation, soil bulk density, depth and texture, which are required inputs for the DSSAT-CSM. These soil types cover more than $90 \%$ of our study area. For climate data for DSSAT simulations we use average air temperature, height of temperature measurements, height of wind measurements, solar radiation, maximum air temperature, minimum air temperature, precipitation, dew-point temperature, wind velocity, and photosynthetic active radiation from a station in Finney County $\left(39{ }^{\circ} \mathrm{N}, 100{ }^{\circ} \mathrm{W}\right)$. Next, we consider a producer's objective function based on the crop production model discussed in this section.

\subsection{Economics component}

The economics component develops a model of an expected profitmaximizing producer considering different irrigation decisions that are available to the producer to apply groundwater. We assume that groundwater is the only source of water supply in the region. The decision variables in our model include the choice of crops, including irrigated and dryland crops, acres of land allocated to each crop, and $P A W_{c}$. 
There are several factors that can affect irrigation decisions and profits of a producer in MOD\$\$A: prices of crops, costs of producing crops per acre excluding irrigation, cost of applying a unit of groundwater, climatic conditions, and well capacity. Well capacity is the maximum flow rate that can be extracted from a groundwater well which can be sustained over a cropping season. Recent literature has shown the importance of having an adequate well capacity for sufficient irrigation supply and how limited well capacity can affect crop yields and profits (Foster et al., 2015; Rouhi Rad et al., 2020) as well as the sensitivity of hydro-economic models to well capacity parameters (Hrozencik et al., 2017). We incorporate well capacity as a factor affecting irrigation decisions through its effect on productivity (Rouhi Rad et al., 2020) to better study the costs of aquifer depletion and benefits of aquifer management policies.

A representative producer determines the number of acres and $P A W_{c}$ allocated to each of the $n$ irrigated crops and $m$ dryland crops to maximize the expected profits:

$$
\begin{aligned}
\operatorname{Max} E \pi= & E_{\text {climate }}\left\{\sum _ { i = 1 } ^ { n } A _ { i } \cdot \left[p _ { i } \cdot f _ { i } \left(w_{i}\left(P A W_{\text {ci }}\right), \operatorname{IFREQ}\left(A-A_{\text {fallow }}\right.\right.\right.\right. \\
& \left.\left.\left.-\sum_{j=n+1}^{n+m} A_{j} ; Q\right), \text { climate, soil }\right)-c \cdot w_{i}-I_{i}\right]+\sum_{j=n+1}^{n+m} A_{j} . \\
& {\left.\left[p_{j} \cdot f_{j}(\text { climate, soil })-I_{j}\right]\right\} }
\end{aligned}
$$

Where $p_{i}$ is the price of irrigated crop, and $p_{j}$ is the price of dryland crop $j . A_{i}$ is the acres of land allocated to irrigated crop $i, A_{j}$ is the acres of land allocated to dryland crop $j$, and $A_{\text {fallow }}$ is the acres of land left fallow. $A=\sum_{i=1}^{n} A_{i}+\sum_{j=n+1}^{n+m} A_{j}+A_{\text {fallow }}$ is the total number of acres that can be irrigated by a given well with an upper bound of 130. $I_{i}$ and $I_{j}$ are the fixed costs per acre, and $c$ is the cost of pumping per unit of groundwater that is independent of crop type but can vary with depth to groundwater. $f_{i}$ is the production function for an irrigated crop $i$ that generates crop yield as a function of the irrigation to crop $i\left(w_{i}\right)$, irrigation frequency (IFREQ), seasonal climatic variables such as rainfall, parcel-level characteristics, such as soil type, and well capacity, $Q . w_{i}$ itself is a function of $P A W_{c i}$ as an increase in $P A W_{c i}$ would result in increases in irrigation. The expectation is over the distribution of climatic variables with equal weight assigned to each historical year.

While most studies within the economics literature consider irrigation as the main decision variable within a stochastic framework, in practice, irrigation decisions are often made by setting soil moisture targets without perfect foresight about the realization of the weather (Foster and Brozović, 2018). It is, thus, important to consider profitmaximizing irrigation decisions that are based on the choice of $P A W_{c}$. With a higher $P A W_{c}$, water application is triggered more frequently during the growing season, resulting in greater seasonal irrigation use. On the other hand, a lower $P A W_{c}$ can decrease crop yield and increase the probability of crop loss.

Well capacity, $Q$, affects crop yield by affecting the rate that the center pivot system can rotate while applying a given depth of water. As a result, we use IFREQ, which is a function of irrigated acres and $Q$, as the mechanism through which well capacity affects crop yield. The relationship between well capacity, irrigation depth, IFREQ, and irrigated acres is given by the following equation:

Irrigated Acres $\times$ irrigation depth $=I F R E Q \times$ Well capacity

The left hand side of Equation 2 is the volume of groundwater applied in terms of area and irrigation depth, while the right hand side of the equation shows the volume of groundwater applied in terms of well capacity and the minimum number of days between the start of two irrigation applications. In MOD\$\$A, irrigation depth is assumed to be around $25 \mathrm{~mm}(\sim 1 \mathrm{inch})$ because at lower irrigation depths the amount of water absorbed by the crop decreases due to surface runoff. Holding irrigation depth fixed at $25 \mathrm{~mm}$, and taking well capacity and irrigation efficiency as given, IFREQ and irrigated acres are the factors that can vary to increase crop water availability. More specifically, a producer can decrease the number of irrigated acres to increase IFREQ so that the acres irrigated are irrigated more frequently than if the entire field was irrigated.

The functional form of Equation 2 introduces a trade-off between irrigating an additional acre and increasing expected crop yield per acre. Irrigating one more acre increases IFREQ per acre. This means that on average, crop yields may be lower for each of the acres irrigated. Moreover, under higher IFREQ's, crop yield will be more sensitive to variation in annual weather conditions.

When used within a hydro-economic framework, the model considers different sources of heterogeneity in physical characteristics of fields, including heterogeneity in soil types and well capacity across space and over time. While producers start with different well capacities, groundwater extraction across space and over time can result in further variation in well capacity across producers.

In numerically estimating profit-maximizing levels of the decision variables in Eq. (2), a custom R script was written (hereafter, R Code 0). In this script, a producer is assumed to irrigate 130 acres, which is the typical size of a quarter section center pivot system. The smallest unit of decision-making in a parcel is a quarter circle (32.5 acres) traversed by a typical pivot. We divide each parcel into four quarter circles where each quarter circle can have a unique crop planted. Each year, for every well with a given soil type and well capacity, based on the prices of each crop and costs of production and irrigation, we estimate the following - First, for each quarter circle, we estimate the expected profit for each crop and $P A W_{c}$. We then find the crop- $P A W_{c}$ combination that maximizes the expected profit in every quarter circle. The sum of irrigation across the four quarter circles determines the field-level irrigation volume, while the sum of the expected profit across these quarters determines the field-level expected profit. Note that given the nonlinear effect of well capacity on expected profits for each crop in each quarter circle, it is possible that different quarter circles will have different crops planted. This nonlinearity results in adjustments in irrigated acres that are different than the one imposed by historical conditions (Howitt, 2005). After the planting and $P A W_{c}$ decisions have been made, during the season daily weather outcomes will be realized. In our case, this is implemented as one of the weather years in the historical weather data. The producer then initiates an irrigation event every time PAW reaches $P A W_{c}$ and when there is enough well capacity. In the next section, we describe the elements of the groundwater model that is used for modeling the spatial and temporal variations in groundwater aquifer levels.

\subsection{Hydrology component}

The groundwater component in MOD\$\$AT is simulated using MODFLOW, one of the most widely used groundwater simulation frameworks. MODFLOW is a free numerical model developed by the USGS in the 1980's. It utilizes the finite difference technique to solve the groundwater flow equation in three dimensions. MODFLOW has a modular structure which enables users to select its different components (packages) based on their objectives. Such modular structure facilitates model construction and optimizes execution time. All models are simplified versions of reality. In MODFLOW, the simplifications depend on model packages. In other words, the choice of packages determines the complexity of the behavior that can be represented.

Our groundwater model builds on the KGS MODFLOW for HPA region in southwest Kansas (Liu et al., 2010). While we focus on Finney County, the KGS MODFLOW model covers parts or all of 23 counties in southwest Kansas, 3 counties in southeast Colorado, and 3 counties in the Oklahoma panhandle. The model is a single-layer model and its uniform and equally spaced cells are $1 \times 1$ mile in size. The model grid consists of 100 rows and 150 columns resulting in 15,000 individual cells, of which 12,083 cells are active. Thus, it covers approximately an 
area of 31,300 square kilometers. Three different boundary conditions are considered in this model by using the flow and head boundary (FHB) package. A time-variant specified head boundary condition is defined for the northern and southern edges of the model domain and a portion of the edges along the bedrock outcrops. For the eastern and western edges of the model, time-variant specified flux is considered as the boundary condition. Remaining edges along the bedrock outcrop regions are defined as time-invariant specified head cells.

To simulate irrigation events, the model uses the well (WEL) package. There are 17,711 wells in the southwestern Kansas portion of the KGS MODFLOW model, of which 1629 irrigation wells are in Finney County. We locate all irrigation wells in the county again to be able to join them to croplands for field-level simulations. Given the size of cells in the model, often more than one well resides in a cell. In that case, the pumping rate is summed across the wells in a cell to determine the extraction rate for the cell. The model utilizes the recharge $(\mathrm{RCH})$ package to simulate recharge from precipitation and irrigation events. The stream (STR) package simulates the groundwater-surface water intercations along the streams and executes stream flow routing calculations. Finally, to model the evapotranspiration in the main riparian regions, e.g. the Arkansas River alluvium, the evapotranspiration (EVT) package is used.

In MODFLOW, a stress period is a set duration during which all external factors such as pumping, recharge, river stage, etc. can affect groundwater flow movement and/or change the amount of water in storage are held constant. The KGS MODFLOW model is constructed based on annual stress periods; i.e. it assumes all stresses like pumping and recharge remain constant throughout a year and updates them at the beginning of each year. In the KGS MODFLOW model the historical simulation is divided into two main periods of predevelopment (1944-1946) and postdevelopment (1947-2007). A steady-state model simulates the predevelopment period to approximate groundwater levels prior to the development of groundwater resources in the region. The steady-state model provides initial conditions for the postdevelopment period, which is simulated by a transient model. In this model, aquifer hydraulic conductivity, aquifer specific yield, streambed hydraulic conductivity, and recharge are considered as the parameters to be calibrated during the historical period by comparing simulated variables such as groundwater table and stream flow to actual measurements through a trial-and-error process. To facilitate the calibration process of the KGS MODFLOW model, PEST which is a parameter estimation software (Doherty, 2007) is employed to optimize the model parameters. Annual pumping at a given well is then distributed evenly throughout the days of the agricultural season, which is 123 days (May 1 - Aug. 31).

So far, in Sections 3.1-3.3, we have described the components of the MOD\$\$AT model. In the next section, we describe the mechanics of integration in this model and how these components are linked.

\subsection{Integration}

The integrated model, MOD\$\$AT, works by first coupling the crop production model (Section 3.1) and the economic model (Section 3.2). The model then couples the generated outcomes of the economic-crop model with the hydrology model (Section 3.3). The crop simulation model, DSSAT, generates output pairs in the form of seasonal water use and harvested crop yield for each irrigation management strategy, i.e., IFREQ and $P A W_{c}$ for each of the crops for each year that we have weather data. As a result, a distribution of profits can be generated from irrigation quantity and crop yields. Furthermore, a distribution of maximum profits for each irrigation strategy and weather-year can be generated from Eq. (1). These outputs can be summarized in the form of a "lookup table".

Using the lookup table means that for an $\mathrm{N}$-year model, we only need to run the profit maximization problem explained in Section 3.2 once for each well capacity and each soil type to generate the lookup table, which is then used in every year of the simulation. The lookup table, however, imposes the behavioral assumption that the expected profit-maximizing producer makes part of the irrigation decision at the beginning of the season and part of the irrigation decision during the irrigation season. Specifically, the producer decides the number of acres and the $P A W_{c}$ allocated to each crop based on the historical distribution of weather variables (in this case a 30-year period from 1980 to 2009) at the beginning of the season. During the season, when weather is realized, the producer irrigates the field based on the chosen $P A W_{c}$. The total seasonal irrigation amount therefore varies from year to year based on weather. The lookup table includes outcomes for every year for which the historical data are available. As a result, it also allows us to generate realizations of groundwater application and crop yields for any given year. Specifically, the lookup table includes profit-maximizing $P A W_{c}$, crop choice, crop yield, and profit for each year of the historical data.

It is worth noting that while in reality, a producer can operate multiple wells or parcels, in the analysis that is done for this representation of the MOD\$AT model, we assume that each producer operates one well which is tied to one 130 acre parcel, which is the size of a typical quarter section center pivot irrigation system across the High Plains Aquifer. ${ }^{1}$ Furthermore, while in theory it is possible to irrigate any portion of the parcel, we limit the analysis to 4 quarter circles of 32.5 acres. In other words, the unit of decision making for a farmer is a quarter of their circle. Finally, the model can be simulated for any number of years. However, in this analysis we use a baseline of 11 years (1997-2007) where the data for both DSSAT and MODFLOW exists. The 50 -year simulation repeats the 11-year weather data while aquifer levels change in response to groundwater extraction. It is easy to see that the analysis can be expanded to different situations and decisionmaking units and none of the points mentioned here are a limitation of the MOD\$\$AT model.

Mechanically, a Windows batch code (.bat) file was written that connects the elements of the model. In year 0 , the batch code first runs the economics $\mathrm{R}$ Code 0 that generates the lookup table. The R Code 0 reads in the outputs of DSSAT model runs and produces profit-maximizing outputs (lookup table). Then, in year 1, the batch code runs a second $\mathrm{R}$ code based on the weather that is realized in that year and selects from the lookup table parcel-level water use and profits. Water use decisions from this economic model are the inputs to the hydrologic model. The batch code runs the MODFLOW model, which generates groundwater head levels at every well. Well capacity, which is an input to the economics model, is then estimated based on the changes in saturated thickness in every cell of the aquifer. The batch code repeats this process for $\mathrm{t}=2, \ldots, \mathrm{N}$. It is worth noting that in $\mathrm{R}$ Code 0 , we simulated a limited number of IFREQ's (Section 3.2). We then linearly interpolated between these discrete values to generate production functions for each value of IFREQ.

Also, running MODFLOW within a loop for years $t=2, \ldots, N$ requires that a new model is run for each water year, using the previous year's water table elevation as an initial condition, because the MODFLOW well package is not easily updated during a model run.

As this simple explanation shows, a major appeal of the MOD\$AT model is the simplicity of the replication. It only needs Windows, DSSAT, MODFLOW and R. DSSAT and MODFLOW are calibrated for different crops and regions respectively. The custom $\mathrm{R}$ code can easily be modified for different regions. All three components of the model, i.e., DSSAT, MODFLOW, and R are freely available to the public.

\section{Results and discussion}

In this section we provide some results that showcase the output of

\footnotetext{
${ }^{1}$ As a result, we use parcel, well and producer interchangeably throughout the manuscript.
} 

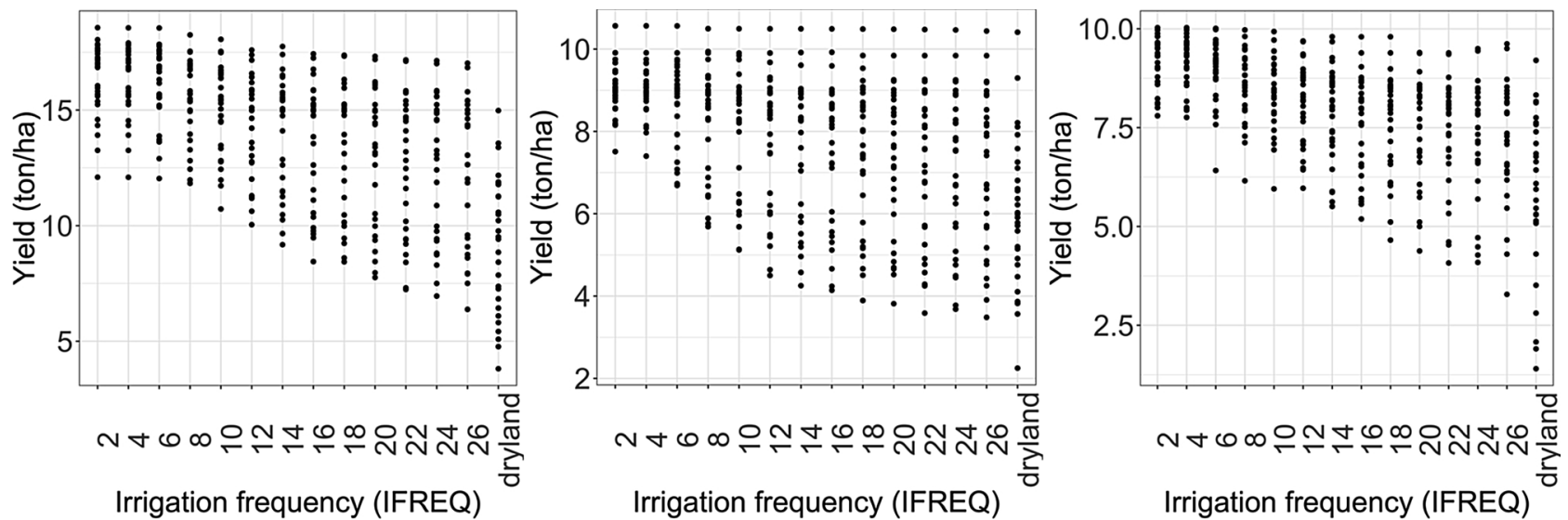

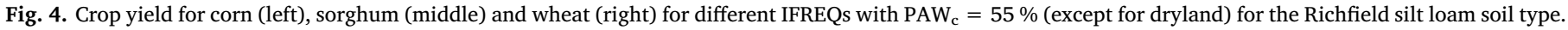

the MOD\$\$AT model. We first discuss the integration of the crop production model and economic model. Together, these two generate a profit-maximizing producer's irrigation decisions. We then discuss the integration of these decisions with the groundwater hydrology model.

\subsection{Producer decision making}

As discussed in Section 3, a producer makes irrigation decisions in two steps. At the beginning of a growing season, the producer determines the number of acres to irrigate, which crop to plant on each quarter circle (32.5 acres), and the $P A W_{c}$ allocated to that crop and quarter circle, given well capacity. To make these decisions, the producer considers the distribution of crop yields and irrigation demand for each crop, IFREQ, and PAW. Fig. 4 shows the distribution of crop yields for different IFREQ's for the Richfield silt loam soil type. Compared to the rest of the soils in the county, this soil type has a relatively higher water holding capacity. Limited water availability, especially during the critical stages of a growing season, can significantly affect crop yield. When IFREQ is higher, i.e., when it takes longer for the center pivot system to irrigate a field and each acre is irrigated less frequently, crop yield is very sensitive to variations in annual weather conditions and, on average, crop yields will be lower on a fixed number of irrigated acres. This is shown in Fig. 4, where lower IFREQ's for all three crops - corn, sorghum and wheat, increase average crop yield and reduce the variance of the crop yield distribution. Also, dryland crops show the lowest average and greatest variance in crop yield for all three crops. Keeping the number of irrigated acres fixed, as well capacity declines, IFREQ increases (Eq. (2)). The figure shows that declining well capacities can result in decreased crop yields on average and increased production risk. During wet years, crop yield is not very sensitive to an increase in IFREQ, as shown by the upper bound of crop yields. ${ }^{2}$ However, during dry years crop yield is increasingly sensitive to changes in IFREQ, as shown by the lower bound of crop yield.

One potential way that a producer can reduce the effects of limited well capacity is by applying more water. Most studies within the economics literature consider irrigation as the main decision variable within a stochastic framework. However, in practice, irrigation decisions are often made by setting a soil moisture target, $P A W_{c}$, without perfect foresight about the realization of the weather (Foster and Brozović, 2018). With a higher $P A W_{c}$, water application is triggered more frequently during the growing season (Kisekka et al., 2016), resulting in greater water use. On the other hand, a lower $P A W_{c}$ can decrease crop yield and increase the probability of crop loss. This is shown

\footnotetext{
${ }^{2}$ It is also worth mentioning that ill-timed rainfall events may affect crop yields. For example, large rainfall events near maturity can cause more harm than good.
}

in Fig. 5, where expected yields for all three crops are higher under higher $P A W_{c}$. However, crop yields seem to be less sensitive to the choice of $P A W_{c}$ compared to the IFREQ values. This suggests that increasing $P A W_{c}$ alone cannot substitute for reductions in well capacities over time and adjustments of other margins, e.g., reducing irrigated acres is required (Rouhi Rad et al., 2020). A $P A W_{c}$ of $50 \%$ is often considered as a practical $\mathrm{PAW}_{\mathrm{c}}$ for irrigation (Klocke et al., 2011). Here, we find that adjusting $P A W_{c}$ could also be one way that a producer can mitigate the costs of aquifer depletion.

Given the distribution of crop yields and water use for different crops, IFREQ's, and $P A W_{c}$, a producer with a given well capacity determines the number of irrigated acres, which crops to grow and $P A W_{c}$ from Eq. (2). Fig. 6 shows the expected profit-maximizing number of acres irrigated, expected seasonal irrigation, and the expected profit for each 130-acre irrigated field (the tabular results are also shown in Table 2). The results show that as well capacity declines, the profitmaximizing producer does not keep irrigated acres fixed and reduces their irrigated acres to be able to keep greater irrigation frequency (IFREQ) on the acres irrigated. Decreasing irrigated acres reduces demand for groundwater. The decline in well capacity also results in a loss of profit for the producer. However, if the producer does not adjust irrigated acres, the loss of profit could be even greater. For the Richfield silt loam, we observe two critical well capacities. First, we see a decline in the profitability of production as well capacity declines below 600 $\mathrm{gpm}$ as the producer decreases groundwater application per acre. Above $600 \mathrm{gpm}$, declining in well capacity do not significantly affect producer profits. As well capacity further declines below $300 \mathrm{gpm}$, the producer reduces the number of irrigated acres. This is also where we start to see significant declines in profitability.

\subsection{Integrated model results}

When integrated with the MODFLOW model, the coupled economiccrop model can generate aquifer levels, well capacities, and profits for each well across the aquifer and over time. We can also study the benefits generated by groundwater management policies to producers. An example of the results of such analysis is shown in Figs. 7 and 8. Each well in the study area has a unique soil type and a unique starting well capacity. As aquifer levels at a well change, well capacities for that well change and the producer responds by adjusting their irrigation decisions as discussed in Section 4.1. A groundwater management policy, such as a pumping tax, can incentivize profit-maximizing producers to reduce their groundwater extraction, which can result in higher relative well capacities over time.

Fig. 7 shows the decline in average well capacity for wells within Finney County under the status quo of no policy and with a pumping tax of $\$ 2$ per acre inch. Taxing groundwater use within the county results in a relative increase in average well capacities over time. This is 

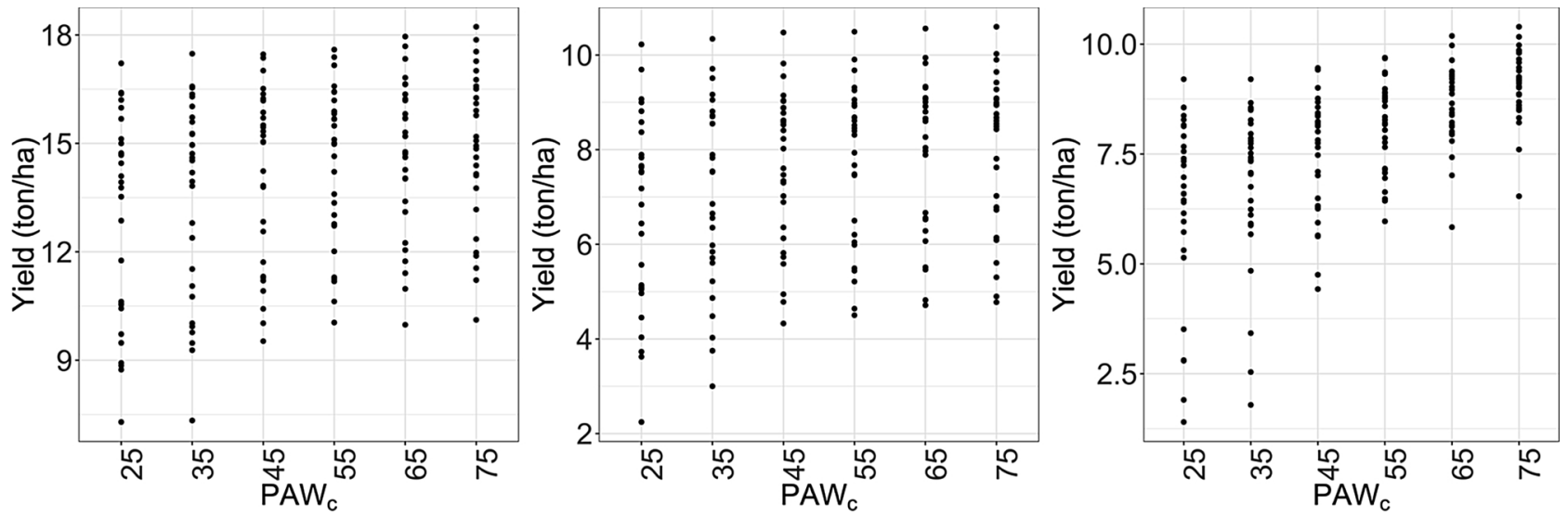

Fig. 5. Crop yield for corn (left), sorghum (middle) and wheat (right) for different $P A W_{c}$ with IFREQ $=12$ for the Richfield silt loam soil type.
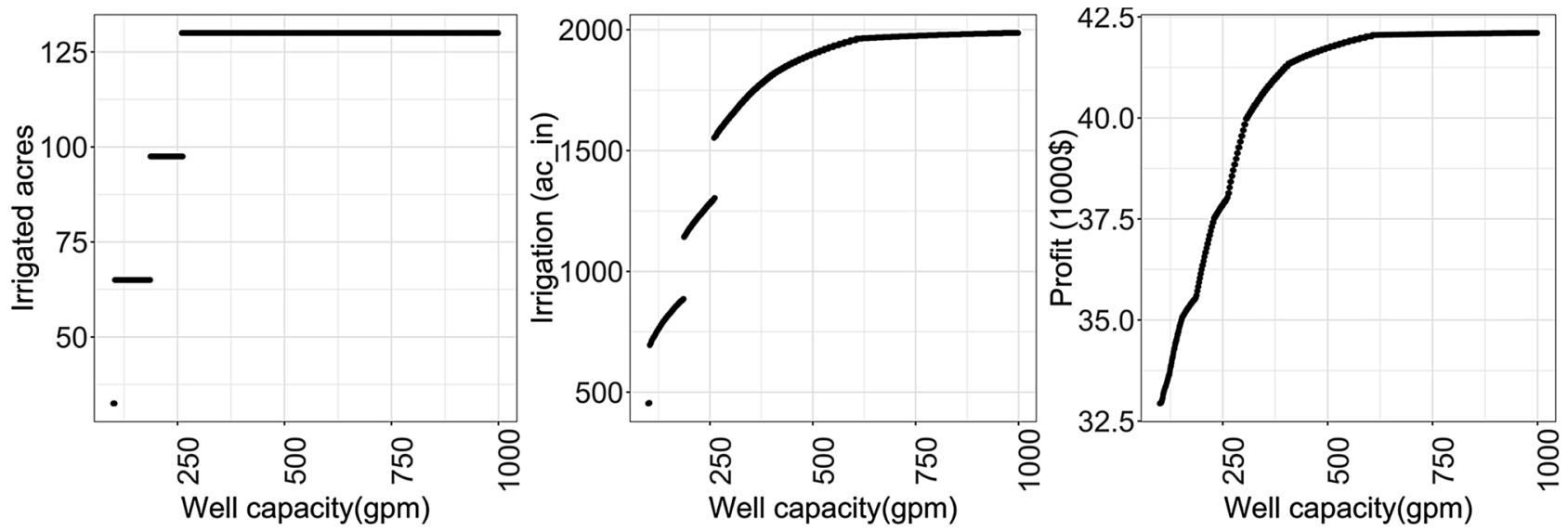

Fig. 6. Parcel-level profit-maximizing number of irrigated acres, irrigation and profits for the Richfield silt loam soil type.

Table 2

Illustration of the lookup table.

\begin{tabular}{|c|c|c|c|c|c|c|c|c|c|c|}
\hline Soil_ID & Well_capacity & Irrigated_acres & IFREQ & Quarter & Crop & PAW & Year & Precipitation & irrigation & profit \\
\hline KS04 & 500 & 130 & 4.9 & 1 & Corn & 75 & 1987 & 340.9 & 543.80 & 28418.91 \\
\hline KS04 & 500 & 130 & 4.9 & 2 & Corn & 75 & 1987 & 340.9 & 543.80 & 28418.91 \\
\hline KS04 & 500 & 130 & 4.9 & 3 & Corn & 75 & 1987 & 340.9 & 543.80 & 28418.91 \\
\hline KS04 & 500 & 130 & 4.9 & 4 & Corn & 75 & 1987 & 340.9 & 543.80 & 28418.91 \\
\hline KS04 & 600 & 130 & 4.1 & 1 & Corn & 75 & 1987 & 340.9 & 543.80 & 28418.91 \\
\hline KS04 & 600 & 130 & 4.1 & 2 & Corn & 75 & 1987 & 340.9 & 543.80 & 28418.91 \\
\hline KS04 & 600 & 130 & 4.1 & 3 & Corn & 75 & 1987 & 340.9 & 543.80 & 28418.91 \\
\hline KS04 & 600 & 130 & 4.1 & 4 & Corn & 75 & 1987 & 340.9 & 543.80 & 28418.91 \\
\hline
\end{tabular}

due to the slower rate of aquifer depletion as a result of the tax. However, the increase in average well capacities from the pumping tax is relatively small. Thus, we may expect small changes in profit as a result of the tax. Fig. 8 shows the spatial distribution of (undiscounted) changes in profitability from the pumping tax. The figure shows that while overall the pumping tax increases the profitability of agricultural production, the benefits of the policy are not uniformly distributed and some wells experience losses in profitability from the tax. The benefits of the policy are higher for producers in the northern part of the county.

While the goal of this paper is to showcase the value of the MOD\$\$AT model and not to do detailed policy analysis, such spatial and temporal analyses of the benefits can help policymakers understand the benefits of different aquifer management policies. These results are important for understanding the distributional effects of different policies and to better identify the winners and losers of the policies. As the equity impacts of policies gain more attention from policymakers, models such as MOD\$ \$AT can become increasingly important. It is also possible to consider the impacts of other policies, such as groundwater quotas, with the MOD\$ \$AT model. In the next section we briefly discuss some of the important elements when building a hydro-economic model.

\section{Discussion and conclusion}

The MOD\$\$T model developed and described in this study makes it possible to study the costs of long-term aquifer depletion and the effects of groundwater management and other agricultural policies. It also allows policymakers to understand the spatial distribution of costs and benefits associated with different groundwater management policies.

Each of the components considered in MOD\$\$A are important for policy analysis. Removing the hydrological element would be similar to considering simplified hydrological models such as the bathtub aquifer model which assumes water levels change simultaneously for all locations across an aquifer (Brozović et al., 2010). Without the hydrological 


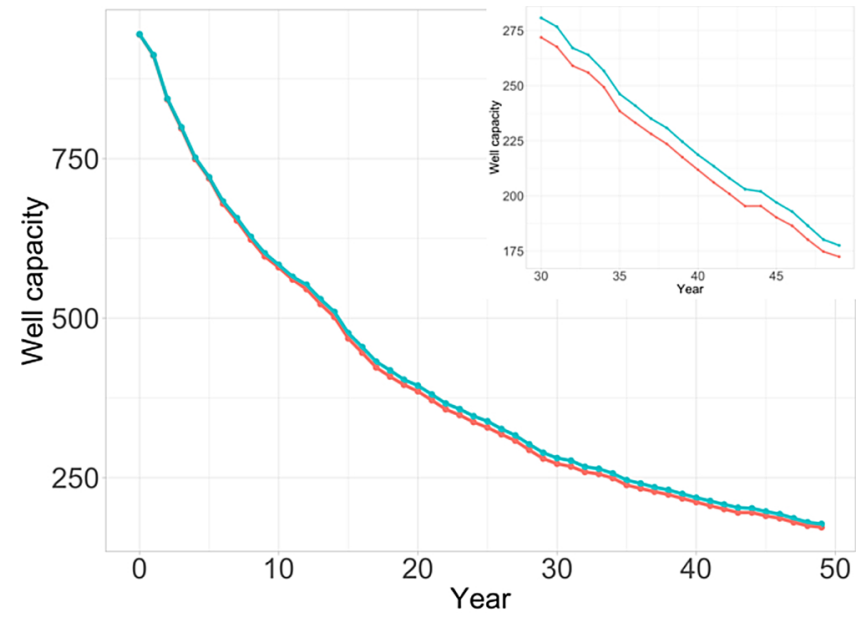

$\operatorname{Tax}(\$ / a c-f t) \rightarrow 0 \rightarrow 24$

Fig. 7. Time trend of average well capacity with and without pumping tax. The figure on the right-hand corner shows the difference in well capacities after year 30 with greater detail.
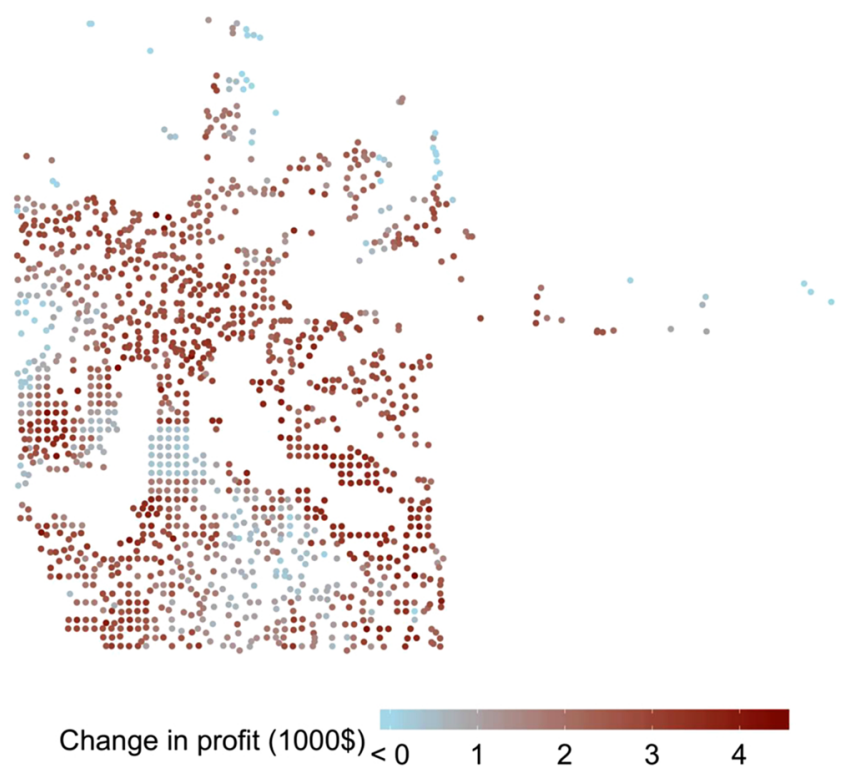

Fig. 8. Spatial distribution of changes in profitability due to a pumping tax. The figure shows the increase in profits for wells across the county in years 40-50 compared to years $0-10$ of the simulation with and without the policy.

model and based on simplifying assumptions, one can analyze the irrigation decisions of a single isolated producer (Foster et al., 2017). However, a model of a single producer cannot accurately estimate changes in aquifer levels and irrigation decisions for an entire aquifer where extraction from one well affects groundwater levels at neighboring wells. Since the effectiveness of a policy depends on the changes in groundwater levels and responsiveness (elasticity) of groundwater demand among neighboring wells to changes in their groundwater levels (Manning and Suter, 2019), ignoring the groundwater model can result in overestimation or underestimation of the policy benefits.

Removing the crop production model means assuming a fixed amount of water applied per acre or fixed crop yield per acre (Brinegar and Ward, 2009; Fenichel et al., 2016). This assumption can result in unrealistic or lack of adjustments in response to changes in water availability. For example, the model may produce the same number of acres irrigated or the same amount of water applied. Alternatively, the relationship between aquifer water-level characteristics or policy variables with well-level groundwater use may be estimated using statistical techniques and historical land and water use decisions (Claassen et al., 2017). While this statistical method can be very accurate in estimating mentioned relationships, it may not be accurate in extrapolating beyond observed values. This especially becomes important when analyzing the effects of a policy where one needs to create counterfactual worlds with and without the policy.

Crop models that include different margins of adjustment can be particularly helpful for studying the effectiveness of different policies ex-ante. For example, these models can help to identify whether the constraints associated with lower well capacities can be mitigated by applying more groundwater by setting higher soil moisture targets. Our results suggest that this is probably not the case. Finally, crop models can also be important for estimating the effects of climate change, as the choice of crops may change over time due to changes in climatic conditions.

The economics model adds a decision-maker to the model. Without a unit of decision-making, the model cannot respond to changes to the system. This lack of response to incentives often means assuming a constant amount of water use over time or ignoring the available margins that a profitmaximizing producer would consider. Either of these assumptions would result in over-estimating rates and costs of aquifer depletion.

Moreover, aquifer management policies are often designed to address specific challenges. These issues may be different from one aquifer to another. For example, while groundwater scarcity and long-term aquifer depletion may be bigger concerns in one aquifer, spatial externalities from groundwater extraction may be the major concern in another aquifer. Another issue often faced is stream depletion due to groundwater extraction, which requires policies that incentivize the reallocation of groundwater extraction away from the river. These problems often require different solutions. Thus, it is important to understand the economic incentives behind the problem at hand in order to propose solutions. Economics can also be useful for comparing different policies. Each policy involves trade-offs in terms of costs and benefits across space and over time. Since the impacts and fairness of different policies are important policy considerations, it is important to understand the costs, benefits, and distribution of different policies.

Model calibration and sensitivity are also important aspects to consider for linked models (Doherty, 2007; Voinov and Shugart, 2013). When parameters from several systems are included in an integrated framework, it becomes more difficult to assess which inputs and parameters are driving the model results. In addition, when parameters are changed during calibration to fit a validation dataset, they can mask the influence of parameters that are not included in the model, or inadvertently overfit, with measurement noise registered as a signal, which diminishes the power of the model to fit out-of-sample measurements. This uncertainty can propagate between systems in integrated models. The software PEST (Parameter ESTimation (Doherty, 2015)) is one example of a program that includes methods for model calibration and sensitivity analysis and is not modelspecific. ${ }^{3}$ All models, but particularly integrated models, should include methodology for their calibration and sensitivity in their documentation, and researchers should consider using a formal framework like PEST to evaluate these important aspects of model rigor.

In developing an integrated modeling framework to study groundwater management, there are a number of judgment calls and assumptions that modelers must make. An understanding of the potential trade-offs associated with these modeling choices and justifications for the assumptions made for MOD\$AT provides some insights for future hydro-economic model development. ${ }^{4}$ For example, when developing a hydro-economic model, it is important to minimize the effects of outcomes that take place outside the spatial boundary of the model. Aquifer boundaries provide a reasonable boundary for the hydro-economic model.

\footnotetext{
${ }^{3}$ PEST is available for free from www.pesthomepage.org.

${ }^{4} \mathrm{~A}$ more detailed description of these judgment calls is provided in the Appendix.
} 
Assumptions and judgement calls specific to the physical system and climate outcomes are also important. When studying the effectiveness of groundwater management policies over the long term, groundwaterlevel changes within a growing season may not be very important. In such a situation, assuming one stress period may be enough. In addition, there is often significant heterogeneity in soil types in a given region. For example, there are seven major soil types in Finney County. These soils, however, do not change significantly over time. On the other hand, climatic variables are relatively stable in small geographic regions but change over time. Thus, it is critical to consider the major soil types in the region and changes in climate over time.

The assumptions related to how agricultural producers behave and how they cope with changes in policy or economic conditions represent critical judgement calls. For example, as well capacities decline, the model must consider how producers adjust critical plant available water thresholds as part of a management strategy. Assumptions related to the timing of irrigation decisions are also important. In practice, crops are planted at the beginning of the season while irrigation applications take place during the season. Our modeling framework assumes that decisions related to the critical plant available water threshold takes place at the beginning of the season, when the farmer does not have perfect information about the weather during the growing season. This threshold then drives irrigation decisions throughout the season, in response to weather realizations. Additionally, producers may form expectations based on different historical periods. For example, whether they consider a 30-year history of seasonal weather, as we assume, or a shorter period, such as the past 10 years, could affect their irrigation decisions and as a result, the effectiveness of a groundwater management policy. The assumed risk preferences of producers can also affect the results of the policy analysis. Under well-developed markets, assuming a risk neutral farmer is reasonable (Antle and Capalbo, 2001) and serves to provide initial insights regarding the effectiveness of the policies. The sensitivity of the results to these assumptions should be considered in future analysis.

MOD\$\$AT also has a few limitations that could be improved upon in future modeling efforts. First, interactions among producers who share a groundwater aquifer could be better represented in future studies. From the hydrological modeling point of view, groundwater models often rely on large cell sizes that include multiple wells. Though this aggregation simplifies the computational process, it may also result in ignoring some of the spatial interactions that exist in practice among neighboring producers. Furthermore, from an economic point of view, these studies often focus on farm-level decision making. However, studies such as Pfeiffer and Lin, 2012 have shown the importance of spatial interactions for groundwater extraction decisions. These behavioral responses, along with better hydrological modeling, can provide better insights on the effectiveness of different policies.

A global optimum, or the first-best solution, is often difficult to achieve under current models due to the computational costs of the estimation. The issue is that aquifer level at each well in the study area is a separate state variable, which results in the curse of dimensionality. Furthermore, the non-convexity of the problem can also affect the chances of achieving the optimal solution. Future models with increased computational power can focus on estimating first-best solutions as they can provide policymakers with an upper bound of what is possible.

Groundwater resources not only include values for production, but they may also generate other values that are not fully captured by the profit-maximization process. For example, producers may also care about the bequest value of groundwater and its availability for future generations (Suter et al., 2020). Hydro-economic models of groundwater management often ignore such values and only consider production profits. Future studies could incorporate non-market and nonuse values that affect groundwater use in hydro-economic models. Finally, in this paper we have not considered the interaction between surface water and groundwater. The incorporation of SWAT-MODFLOW (Bailey et al., 2016), a linked surface- and groundwater model, will enable a more holistic approach to impacts to the water cycle due to agriculture, whether mediated by withdrawals, or changes in precipitation partitioning (runoff and recharge).

\section{Declaration of interest}

None.

\section{Appendix A. Judgment calls}

\section{Judgment call 1. Locating the integrated model in space}

Neither the typical crop model nor the typical economic model is specifically rooted in any single location. Crop models are generally onedimensional and the modeling unit is assumed to have uniform properties. Economics models often work at the field level. For example, a producer decides how many acres of a given field they should irrigate. Hydrologic models, on the other hand, rely on the spatial characteristics of large physical systems, and one of their primary purposes is the calculation of flux from one location to another within the model area. This means that the definition of the system in space becomes very important.

Hydro-economic models of groundwater management are often implemented within administrative or watershed boundaries (Bulatewicz et al., 2010). Regional groundwater flow may not respect such boundaries. Functionally, it means that boundary conditions must be chosen, preferably, in a location where the other side of the boundary has as little influence as possible on the model outcome. For groundwater, this is often a river (a hydraulic barrier) or a geologically defined aquifer boundary like bedrock outcrop (a geologic barrier). Vertical layering may be more difficult to characterize, and large-scale, regional models are often constructed with a single layer representing the effective characteristics of various hydrogeological units that are subsumed within that layer (Rossman and Zlotnik, 2013). It is best if the model boundaries are chosen such that the field where irrigation decisions are made are close to the center of the hydrologic model, to avoid controlling effects of boundary conditions as they can confound the effects of changes in water availability. In the case of the MOD\$\$T example presented here, the boundary conditions are chosen to be the edge of the aquifer materials where possible, with an erosional feature that cuts through the aquifer to the bedrock. Groundwater flux on one side of this boundary is completely independent of the water table on the other side of the ravine. In some edges of the model, there are no such clear features, but boundaries are selected in areas where the model includes changing head boundary conditions over time, to try to diminish edge effects. This constraint in model boundary selection may make it difficult to predict water levels far into the future, since it relies on well measurements to characterize these boundaries.

\section{Judgment call 2. Temporal discretization}

Groundwater moves slowly, and so hydrologic models tend to have longer timesteps than other models. A balance of stress periods is required to compromise between model simplicity and correctness. Crop models keep track of soil moisture and therefore are sensitive to pumping on a daily time-step; the danger is in enabling the crop to be watered more frequently than a pivot arm would physically be able to get around the field. 
Hydrologic models are more likely to assume constant pumping over the entire growing season so that the growing season can be simulated with a single stress period. This may not adequately describe the system from the point of view of the crop and economic components of an integrated model. For example, some coping strategies might involve planting different irrigated crops at different times of the year so that limited capacity can be used over a longer portion of the growing season. However, adding such details within a growing season can increase the uncertainty of the model as no model can exactly model the planting days or the days in which irrigation takes place accurately. Moreover, even if such decisions can be modeled, their effect on groundwater flow over long time period that are relevant for policy is relatively small. For example, the effect of irrigating once a week at a given volume and irrigating every day at one seventh of that volume is relatively small at the beginning of the next irrigation season. As a result, we assume a single stress period for each year.

\section{Judgment call 3. Irrigation management strategies}

Different irrigation management strategies can be used to reduce water use or to increase crop yield. In MOD\$\$AT, we consider $P A W_{c}$, IFREQ, choice of crops, and irrigated acres. While there are many other ways to reduce water use, these decisions depend on the context. For example, reducing irrigation depth below $25 \mathrm{~mm}$ is not often observed in our study region. As a result, we assume irrigation depth to be fixed. We also note that there are other strategies that may not seem to affect irrigation directly, but they can still affect water use. Examples of such management strategies include changing the planting density of seeds per acre or changing planting and harvest dates. These strategies can especially become important under a changing climate. In the current version of MO\$\$AT, we do not consider these decisions and we only consider changes in the combination of crops, irrigated acres, and amount of irrigation applied per acre. While it is expected that adding more irrigation and planting decisions can result in lower costs of aquifer depletion and aquifer management policies because producers can respond by changing multiple decisions, future studies can study the importance and extent of decisions such as changing planting density for adaptation to declining aquifer levels.

\section{Judgment call 4. Which crops to grow?}

A range of crops can be considered for production. When it comes to the choice of crops to be considered by the integrated model, the objectives of the study are important. If the goal is to determine the effectiveness of different policies to reduce water use in the short run, it is better to rely on existing crops within the region. However, if the goals of the policy are to manage water use in the long run, we need to consider different crops that can become profitable under different conditions. Not considering such crops in the decision space can result in over-estimating the costs of aquifer depletion.

Furthermore, to correctly capture the costs and benefits of producing different crops, we need to consider how a producer makes irrigation decisions under uncertainty. To do so, we need to capture the distribution of crop yields under different weather conditions. In this study, we use 30 years of historic weather data (from 1980 to 2009) to capture the observed long-term variability noted in the recent history for three of the major crops in the study area, i.e., corn, sorghum and wheat. Future research could focus on better understanding the distribution of climatic variables that producers consider when making irrigation decisions. If producers consider a shorter period of historical weather outcomes, this can potentially bias the results generated with the entire range of historical weather outcomes, e.g., the 30-year period considered in this study if the recent weather outcomes are different from the historical weather.

\section{Judgment call 5. Heterogeneity of climatic variables across the study area and over time}

This judgment call is related to both data availability and the importance of heterogeneity of different variables across space and over time. Crop production models, such as DSSAT, often require high-quality weather and soils data to simulate daily crop growth. Modeled climate data such as those generated by the PRISM group (PRISM, 2019) do not include the variables that are needed for the agronomic models. As a result, the spatial heterogeneity in the effect of climatic variables is limited by the availability of station data. Furthermore, often climate does not vary significantly across a small study area such as the one considered in this paper. As a result, when the study area is relatively small, one can assume a homogeneous climate across the study area. However, climate does change over time and considering the temporal change in climate could be important for studying trends of aquifer depletion over the long term. On the other hand, even in small areas, biophysical characteristics, such as soil type, tend to be more heterogeneous. These factors often vary at local scales, but less so over time, and can have important implications for crops' water use and productivity. For example, water holding capacity can vary substantially across soil types which can affect irrigation decisions and crop choice. In the analysis in this paper, we used seven different soil types that cover more than $90 \%$ of the area of Finney county. However, we used climate data only for one weather station within the county.

\section{Judgment call 6. Risk preferences of the producers}

Our model assumes a risk-neutral producer who is interested in short-term gains (i.e., a myopic producer). Groundwater is a common property resource where property rights for the resource are usually not well defined. The groundwater economics literature suggests that under such circumstances, the assumption of a myopic producer is reasonable (Knapp and Olson, 1995; Koundouri, 2004). Furthermore, while there are uncertainties involved in agricultural production, conventionally most models assume a risk-neutral producer and those that assume risk aversion often find small changes in the value of groundwater management (Koundouri, 2004). Uncertainty in weather and surface water availability can be included in the model of irrigation decision-making without necessarily considering risk-averse producers. For example, in studying the buffer value of an aquifer, (Tsur and Graham-Tomasi, 1991) consider uncertainty independent of risk aversion. They show that compared to the deterministic case, under uncertainty, even when producers are risk-neutral, groundwater is more valuable in buffering against variations in rainfall. This is explained by Jensen's Inequality- for nonlinear functions, a function of the mean is different from the mean of the function. Thus, while we can relax risk aversion, estimating crop yield and profits for mean climatic variables such as temperature and precipitation results in a biased demand for water, crop yields, and profits (Fig. A1). Furthermore, the model of a risk-neutral producer may sometimes provide more insight as it reduces the need for strong assumptions regarding the functional form and parameters of risk preferences.

We also assume constant returns to scale production in irrigated and dryland acres. Constant returns to scale assumptions mean that land quality 


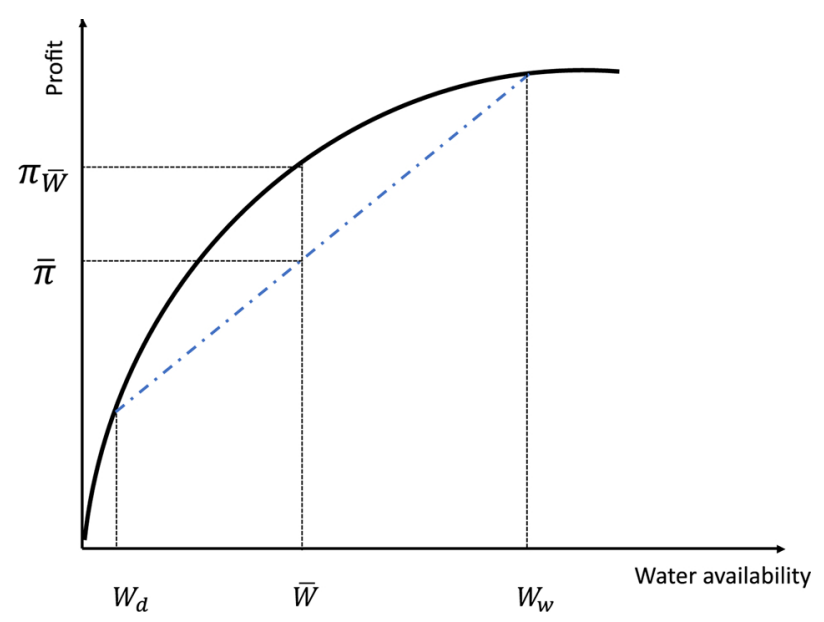

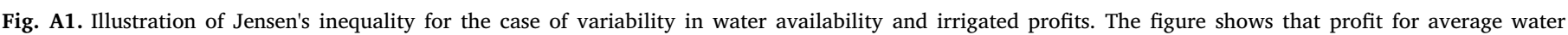
availability is greater than average profit.

is homogeneous for a given parcel. More specifically, if $\tilde{y}$ is crop yield for an acre of irrigated production, adding $\widetilde{a}$ irrigated acres would increase harvestable crop biomass by $\tilde{a y}$. While there is often heterogeneity in local land characteristics, traditionally within field physical characteristics has been assumed to be homogeneous. It is unlike that the profit-maximization results are sensitive to such small-scale heterogeneity, though future research could further explore this sensitivity.

\section{Judgment call 7. Timing of irrigation decisions in a growing season}

Another important behavioral assumption is the timing of irrigation decisions. One can model certain day to day irrigation decisions. However, modeling at such fine scales may result in an inaccurate modeling of the decision-making process. As a result, we assume that the producer decides on an irrigation rule ex ante, but the amount applied is responsive to weather. At the beginning of a growing season, a producer makes decisions regarding which crops to grow and acres of land allocated to each crop. We also assume that the producer simultaneously determines the $P A W_{c}$. Determining $P A W_{c}$ at the beginning of the season creates a trade-off. On the one hand, it assumes that farmers commit to a certain $P A W_{c}$ for each crop at the beginning of the season, only adjusting groundwater application based on the weather in that year. On the other hand, it relaxes the assumption that farmers have perfect foresight about the weather and are willing to adapt their irrigation practices based on field requirements (Foster and Brozović, 2018). We believe that correctly capturing the behavioral responses to available weather information is important for reliability of the results. However, future research can further explore the sensitivity of demand for groundwater when multiple $P A W_{c}^{\prime}$ s during a given growing season is considered.

Judgment call 8. The dependency of irrigation frequency on acres irrigated and well capacity

In theory, there are two ways that IFREQ can affect crop yield depending on crop water demand and irrigation practices. First, irrigating fewer acres of a parcel can increase the amount of groundwater that can be applied per acre per day. Second, irrigating fewer acres of crop $i, A_{i}$, can increase the amount of groundwater that can be applied per acre per day to that crop. The difference is whether irrigating the two crops coincide during the growing season. In the case that the days that crop 1 is irrigated does not coincide with that of crop 2, one can assume the latter case. However, it is likely that during the season, at least once, irrigating crop 1 will coincide with crop 2 . In this case, it is more conservative to assume that IFREQ for crop $i$ depends on the total number of irrigated acres rather than irrigated acres of crop $i$. However, the farmer controls the application rate when the pivot moves from one crop to another through the choice of $P A W_{c}$. This is what we assume in MOD\$\$AT.

Judgment call 9. Using a lookup table for the numerical outputs of Eq. (1)

Ideally, there is a link between day to day irrigation decisions and crop growth. However, as discussed, daily irrigation decisions are not known with certainty, and we use seasonal decisions instead. As a result, we can generate a lookup table (Table 2) that provides us with groundwater use and crop yield for different well capacities, soil types, and weather types. Using a lookup table significantly decreases the computational cost of integration when all the farms are similar in size and have similar choice set, i.e., irrigation decisions such as crops to grow, $P A W_{c}$, etc. However, the computational cost of a look up table may be high when farms have different irrigation strategies available to them. In MOD\$\$AT we assume that each parcel is 130 acres and is irrigated with one well.

\section{Judgment Call 10. Hydro-economic model under a changing climate}

Climate change can increase the total volume and variability of rainfall during the growing season (Pendergrass et al., 2017). Under such conditions, groundwater can play an increasingly important role to buffer against the variations in rainfall (including extreme events such as droughts). Over time, producers have increasingly relied on groundwater (Hornbeck and Keskin, 2014), making their yield more contingent on stability in the system. Thus, understanding the costs of joint climate change and aquifer depletion is very important. Hydro-economic models can be designed to show a variety of scenarios to quantify impacts to irrigators (Hurd and Rouhi-Rad, 2013); stand-alone hydrology and economic models risk missing important processes because of their typical simplifying assumptions. The MOD\$\$AT can also be used in estimating the costs of climate 
change along with aquifer depletion. While we have not specifically discussed the incorporation of data from climate simulations to study the potential impacts of climate change, as long as the downscaled climate data is generated for the study area that can be used in DSSAT and MODFLOW, we can easily include such data to study the impacts of climate change. In that case, recharge rates are simulated based on the simulated climate data. Similarly, crop yields and water use values are also updated. An interesting question raised here is whether producers take into account the simulated future climate or historical observed climate when making irrigation decisions. Future research could further explore such behavioral responses.

Finally, we should note that the choices that the producers face are often structurally added to the model as a set of choices. In the long run, producers may adopt different practices, such as drought-tolerant seed varieties that are not invented yet, that reduce the impacts of climate change. To the extent that such innovations determine future water use, MOD\$\$A, an in general hydro-economic models, will over-estimate the rate of aquifer depletion. The economics literature on the impacts of climate change has emphasized the role of adaptation (Mendelsohn et al., 1994) and shows that ignoring adaptation and margins of adjustment can result in over-estimating the costs of climate change.

\section{References}

Adamowicz, W., Calderon-Etter, L., Entem, A., Fenichel, E.P., Hall, J.S., Lloyd-Smith, P., Ogden, F.L., Regina, J.A., Rad, M.R., Stallard, R.F., 2019. Assessing ecological infrastructure investments. Proc. Natl. Acad. Sci. U.S.A. https://doi.org/10.1073/pnas. 1802883116

Almas, L.K., Colette, W.A., Wu, Z., 2004. Declining ogallala aquifer and texas panhandle economy. Southern Agricultural Economics Association Annual Meeting 1-20. https://doi.org/10.22004/AG.ECON.34646.

Antle, J.M., Capalbo, S.M., 2001. Econometric-process models for integrated assessment of agricultural production systems. Am. J. Agric. Econ. 83 (2), 389-401. https://doi. org/10.1111/0002-9092.00164.

Araya, A., Kisekka, I., Gowda, P.H., Prasad, P.V.V., 2018. Grain sorghum production functions under different irrigation capacities. Agric. Water Manag. https://doi.org/ 10.1016/j.agwat.2018.03.010.

Araya, A., Gowda, P.H., Golden, B., Foster, A.J., Aguilar, J., Currie, R., Ciampitti, I.A., Prasad, P.V.V., 2019. Economic value and water productivity of major irrigated crops in the Ogallala aquifer region. Agric. Water Manag. https://doi.org/10.1016/j.agwat. 2018.11.015.

Bailey, R.T., Wible, T.C., Arabi, M., Records, R.M., Ditty, J., 2016. Assessing regionalscale spatio-temporal patterns of groundwater-surface water interactions using a coupled SWAT-MODFLOW model. Hydrol. Process. https://doi.org/10.1002/hyp. 10933.

Boote, K.J., Jones, J.W., Pickering, N.B., 1996. Potential uses and limitations of crop models. Agron. J. https://doi.org/10.2134/agronj1996.00021962008800050005x.

Brinegar, H.R., Ward, F.A., 2009. Basin impacts of irrigation water conservation policy. Ecol. Econ. https://doi.org/10.1016/j.ecolecon.2009.07.020.

Brown, C.M., Lund, J.R., Cai, X., Reed, P.M., Zagona, E.A., Ostfeld, A., Hall, J., Characklis, G.W., Yu, W., Brekke, L., 2015. The future of water resources systems analysis: toward a scientific framework for sustainable water management. Water Resour. Res. https://doi.org/10.1002/2015WR017114.

Brozović, N., Sunding, D.L., Zilberman, D., 2010. On the spatial nature of the groundwater pumping externality. Resour. Energy Econ. https://doi.org/10.1016/j. reseneeco.2009.11.010.

Bulatewicz, T., Yang, X., Peterson, J.M., Staggenborg, S., Welch, S.M., Steward, D.R., 2010. Accessible integration of agriculture, groundwater, and economic models using the Open Modeling Interface (OpenMI): methodology and initial results. Hydrol. Earth Syst. Sci. 14 (3), 521-534. https://doi.org/10.5194/hess-14-521-2010.

Claassen, R., Langpap, C., Wu, J., 2017. Impacts of federal crop insurance on land use and environmental quality. Am. J. Agric. Econ. 99 (3), 592-613. https://doi.org/10. 1093/ajae/aaw075.

Das, Biswa, Willis, David, Rainwater, Ken, 2013. An interdisciplinary regional groundwater model: A study of the Ogallala in the Texas High Plains. Regional Science Policy \& Practice.

Deines, J.M., Kendall, A.D., Butler, J.J., Hyndman, D.W., 2019. Quantifying irrigation adaptation strategies in response to stakeholder-driven groundwater management in the US High Plains Aquifer. Environ. Res. Lett. 14 (4), 044014. https://doi.org/10. 1088/1748-9326/aafe39.

Dogan, M.S., Fefer, M.A., Herman, J.D., Hart, Q.J., Merz, J.R., Medellín-Azuara, J., Lund, J.R., 2018. An open-source Python implementation of California's hydroeconomic optimization model. Environ. Model. Softw. 108, 8-13. https://doi.org/10.1016/j. envsoft.2018.07.002.

Doherty, J., 2007. Use of PEST and Some of its Utilities in Model Calibration and Predictive Error Variance Analysis:-A Roadmap prepared by Watermark Numerical Computing.

Doherty, J., 2015. Calibration and uncertainty analysis for complex environmental models. Groundwater 53 (5), 673-674.

Fenichel, E.P., Abbott, J.K., Bayham, J., Boone, W., Haacker, E.M.K., Pfeiffer, L., 2016. Measuring the value of groundwater and other forms of natural capital. Proc. Natl. Acad. Sci. U.S.A. https://doi.org/10.1073/pnas.1513779113.

Foster, T., Brozović, N., 2018. Simulating crop-water production functions using crop growth models to support water policy assessments. Ecol. Econ. https://doi.org/10 1016/j.ecolecon.2018.05.019.

Foster, T., Brozović, N., Butler, A.P., 2015. Analysis of the impacts of well yield and groundwater depth on irrigated agriculture. J. Hydrol. https://doi.org/10.1016/j. jhydrol.2015.01.032.

Foster, T., Brozović, N., Butler, A.P., 2017. Effects of initial aquifer conditions on economic benefits from groundwater conservation. Water Resour. Res. https://doi.org/
10.1002/2016WR019365

George, Biju, Malano, Hector, Davidson, Brian, Hellegers, Petra, Bharati, Luna, Massuel, Sylvain, 2011. An integrated hydro-economic modelling framework to evaluate water allocation strategies I: Model development. Agricultural Water Management.

Gisser, M., Sánchez, D.A., 1980. Competition versus optimal control in groundwater pumping. Water Resour. Res. https://doi.org/10.1029/WR016i004p00638.

Guilfoos, T., Khanna, N., Peterson, J.M., 2016. Efficiency of viable groundwater management policies. Land Econ. https://doi.org/10.3368/le.92.4.618.

Haacker, E.M.K., Sharda, V., Cano, A.M., Hrozencik, R.A., Núñez, A., Zambreski, Z., Nozari, S., Smith, G.E.B., Moore, L., Sharma, S., Gowda, P., Ray, C., Schipanski, M., Waskom, R., 2019. Transition pathways to sustainable agricultural water management: a review of integrated modeling approaches. J. Am. Water Resour. Assoc. https://doi.org/10.1111/1752-1688.12722.

Harou, J.J., Pulido-Velazquez, M., Rosenberg, D.E., Medellín-Azuara, J., Lund, J.R., Howitt, R.E., 2009. Hydro-economic models: concepts, design, applications, and future prospects. J. Hydrol. https://doi.org/10.1016/j.jhydrol.2009.06.037.

Hoogenboom, G., Porter, C.H., Shelia, V., Boote, K.J., Singh, U., White, J.W., Hunt, L.A., Ogoshi, R., Lizaso, J.I., Koo, J., Asseng, S., Singels, A., Moreno, L.P., Jones, J.W., 2017. Decision Support System for Agrotechnology Transfer (DSSAT) Version 4.7.

Hornbeck, R., Keskin, P., 2014. The historically evolving impact of the ogallala aquifer: agricultural adaptation to groundwater and drought. Am. Econ. J. Appl. Econ. https://doi.org/10.1257/app.6.1.190.

Housh, M., Cai, X., Ng, T.L., McIsaac, G.F., Ouyang, Y., Khanna, M., Sivapalan, M., Jain, A.K., Eckhoff, S., Gasteyer, S., Al-Qadi, I., Bai, Y., Yaeger, M.A., Ma, S., Song, Y., 2015. System of systems model for analysis of biofuel development. J. Infrastruct. Syst. 21 (3), 04014050. https://doi.org/10.1061/(ASCE)IS.1943-555X.0000238.

Howitt, R.E., 2005. PMP Based Production Models-Development and Integration. XIth EAAE Congress (European Association of Agricultural Economists). https:// ageconsearch.umn.edu/record/24484/files/os05ho01.pdf.

Hrozencik, R.A., Manning, D.T., Suter, J.F., Goemans, C., Bailey, R.T., 2017. The heterogeneous impacts of groundwater management policies in the Republican River Basin of Colorado. Water Resour. Res. https://doi.org/10.1002/2017WR020927.

Hurd, B., Rouhi-Rad, M., 2013. Estimating economic effects of changes in climate and water availability. Clim. Change. https://doi.org/10.1007/s10584-012-0636-9.

Jaeger, W.K., Amos, A., Bigelow, D.P., Chang, H., Conklin, D.R., Haggerty, R., Langpap, C., Moore, K., Mote, P.W., Nolin, A.W., Plantinga, A.J., Schwartz, C.L., Tullos, D., Turner, D.P., 2017. Finding water scarcity amid abundance using human-natural system models. Proc. Natl. Acad. Sci. U.S.A. https://doi.org/10.1073/pnas. 1706847114.

Jones, J.W., Hoogenboom, G., Porter, C.H., Boote, K.J., Batchelor, W.D., Hunt, L.A., Wilkens, P.W., Singh, U., Gijsman, A.J., Ritchie, J.T., 2003. The DSSAT cropping system model. Eur. J. Agron. https://doi.org/10.1016/S1161-0301(02)00107-7.

Kahil, M.T., Ward, F.A., Albiac, J., Eggleston, J., Sanz, D., 2016. Hydro-economic modeling with aquifer-river interactions to guide sustainable basin management. J. Hydrol. https://doi.org/10.1016/j.jhydrol.2016.05.057.

Kisekka, I., Aguilar, J.P., Rogers, D.H., Holman, J., O’Brien, D.M., Klocke, N., 2016. Assessing deficit irrigation strategies for corn using simulation. Trans. ASABE 59 (1), 303-317. https://doi.org/10.13031/trans.59.11206.

Klocke, N.L., Currie, R.S., Tomsicek, D.J., Koehn, J., 2011. Corn yield response to deficit irrigation. Trans. ASABE. https://doi.org/10.13031/2013.37118.

Knapp, K.C., Olson, L.J., 1995. The economics of conjunctive groundwater management with stochastic surface supplies. J. Environ. Econ. Manage. https://doi.org/10.1006/ jeem.1995.1022.

Koundouri, P., 2004. Potential for groundwater management: Gisser-Sanchez effect reconsidered. Water Resour. Res. https://doi.org/10.1029/2003WR002164.

MacEwan, D., Cayar, M., Taghavi, A., Mitchell, D., Hatchett, S., Howitt, R., 2017. Hydroeconomic modeling of sustainable groundwater management. Water Resour. Res. 53 (3), 2384-2403. https://doi.org/10.1002/2016WR019639.

Manning, D.T., Suter, J.F., 2019. Production externalities and the gains from management in a spatially-explicit aquifer. J. Agric. Resour. Econ.

McNider, R.T., Handyside, C., Doty, K., Ellenburg, W.L., Cruise, J.F., Christy, J.R., Moss, D., Sharda, V., Hoogenboom, G., Caldwell, P., 2015. An integrated crop and hydrologic modeling system to estimate hydrologic impacts of crop irrigation demands. Environ. Model. Softw. https://doi.org/10.1016/j.envsoft.2014.10.009.

Medellín-Azuara, Josué, MacEwan, Duncan, Howitt, Richard E., Koruakos, George, Dogrul, Emin C., Brush, Charles F., Kadir, Tariq N., Harter, Thomas, Melton, Forrest, Lund, Jay R., 2015. Hydro-economic analysis of groundwater pumping for irrigated agriculture in California's Central Valley, USA. Hydrogeology journal.

Mendelsohn, R., Nordhaus, W.D., Shaw, D., 1994. The impact of global warming on 
agriculture: a Ricardian analysis. Am. Econ. Rev. https://doi.org/10.1257/aer.89.4. 1049.

Mitchel, D., Williams, R., Johnson, P., 2016. An Economic Analysis to Determine the Feasibility of Groundwater Supplementation From the Dockum Aquifer. Southern Agricultural Economics Association. https://ageconsearch.umn.edu/record/ $230069 /$.

Monteith, J.L., 1996. The quest for balance in crop modeling. Agron. J. https://doi.org/ 10.2134/agronj1996.00021962008800050003x.

Mulligan, K.B., Brown, C., Yang, Y.C.E., Ahlfeld, D.P., 2014. Assessing groundwater policy with coupled economic-groundwater hydrologic modeling. Water Resour. Res. 50 (3), 2257-2275. https://doi.org/10.1002/2013WR013666.

Pendergrass, A.G., Knutti, R., Lehner, F., Deser, C., Sanderson, B.M., 2017. Precipitation variability increases in a warmer climate. Sci. Rep. 7 (1), 1-9. https://doi.org/10. 1038/s41598-017-17966-y.

Pfeiffer, L., Lin, C.Y.C., 2012. Groundwater pumping and spatial externalities in agriculture. J. Environ. Econ. Manage. https://doi.org/10.1016/j.jeem.2012.03.003.

Rodell, M., Famiglietti, J.S., Wiese, D.N., Reager, J.T., Beaudoing, H.K., Landerer, F.W., Lo, M.H., 2018. Emerging trends in global freshwater availability. Nature 557 (7707), 651-659. https://doi.org/10.1038/s41586-018-0123-1.

Rossman, N.R., Zlotnik, V.A., 2013. Revue: Modélisation régionale des écoulements souterrains dans des bassins avec une forte irrigation dans des états sélectionnés de l'Ouest des Etats-Unis d'Amérique. Hydrogeol. J. 21 (6), 1173-1192. https://doi.org/ 10.1007/s10040-013-1010-3.

Rouhi Rad, M., Brozović, N., Foster, T., Mieno, T., 2020. Effects of instantaneous groundwater availability on irrigated agriculture and implications for aquifer management. Resour. Energy Econ. 59, 101129. https://doi.org/10.1016/j.reseneeco.
2019.101129.

Scanlon, B.R., Faunt, C.C., Longuevergne, L., Reedy, R.C., Alley, W.M., McGuire, V.L., McMahon, P.B., 2012. Groundwater depletion and sustainability of irrigation in the US High Plains and Central Valley. Proc. Natl. Acad. Sci. U.S.A. https://doi.org/10. 1073/pnas.1200311109.

Sharda, V., Gowda, P.H., Marek, G., Kisekka, I., Ray, C., Adhikari, P., 2019. Simulating the impacts of irrigation levels on soybean production in Texas High Plains to manage diminishing groundwater levels. J. Am. Water Resour. Assoc. https://doi.org/10. 1111/1752-1688.12720.

Steward, D.R., Bruss, P.J., Yang, X., Staggenborg, S.A., Welch, S.M., Apley, M.D., 2013. Tapping unsustainable groundwater stores for agricultural production in the High Plains Aquifer of Kansas, projections to 2110. Proc. Natl. Acad. Sci. U.S.A. https:// doi.org/10.1073/pnas.1220351110.

Suter, J.F., Rouhi Rad, M., Manning, D.T., Goemans, C., Sanderson, M.R., 2020. Depletion, climate, and the incremental value of groundwater. Resour. Energy Econ. 101143. https://doi.org/10.1016/j.reseneeco.2019.101143.

Thorp, K.R., DeJonge, K.C., Kaleita, A.L., Batchelor, W.D., Paz, J.O., 2008. Methodology for the use of DSSAT models for precision agriculture decision support. Comput. Electron. Agric. https://doi.org/10.1016/j.compag.2008.05.022.

Tsur, Y., Graham-Tomasi, T., 1991. The buffer value of groundwater with stochastic surface water supplies. J. Environ. Econ. Manage. https://doi.org/10.1016/00950696(91)90027-G.

Voinov, A., Shugart, H.H., 2013. "Integronsters", integral and integrated modeling. Environ. Model. Softw. https://doi.org/10.1016/j.envsoft.2012.05.014.

Whittemore, D., 2012. Ground-water recharge in the Upper Arkansas River corridor in southwest Kansas. 